\title{
Assessing Changes and Associations in the Xanthomonas perforans Population Across Florida Commercial Tomato Fields Via a Statewide Survey
}

\author{
Jeannie M. Klein-Gordon, ${ }^{1,2}$ Yanru Xing, ${ }^{1,2,3}$ Karen A. Garrett, ${ }^{1,2,3, \dagger}$ Peter Abrahamian, ${ }^{1,4}$ Matthews L. Paret, ${ }^{1,5}$ \\ Gerald V. Minsavage, ${ }^{1}$ Amanda L. Strayer-Scherer, ${ }^{6}$ James C. Fulton, ${ }^{1}$ Sujan Timilsina, ${ }^{1}$ Jeffrey B. Jones, ${ }^{1}$ \\ Erica M. Goss, ${ }^{1,2}$ and Gary E. Vallad ${ }^{1,4, \dagger}$ \\ ${ }^{1}$ Department of Plant Pathology, Institute of Food and Agricultural Sciences, University of Florida, Gainesville, FL 32611 \\ ${ }^{2}$ Emerging Pathogens Institute, University of Florida, Gainesville, FL 32611 \\ ${ }^{3}$ Food Systems Institute, University of Florida, Gainesville, FL 32611 \\ ${ }^{4}$ Gulf Coast Research and Education Center, Institute of Food and Agricultural Sciences, University of Florida, Balm, FL 33598 \\ ${ }^{5}$ North Florida Research and Education Center, Institute of Food and Agricultural Sciences, University of Florida, Quincy, FL 32351 \\ ${ }^{6}$ Department of Entomology and Plant Pathology, Auburn University, Auburn, AL 36849 \\ Accepted for publication October 2020.
}

\begin{abstract}
Before 1991, Xanthomonas euvesicatoria was the causal agent of bacterial spot of tomato in Florida but was quickly replaced by $X$. perforans. The $X$. perforans population has changed in genotype and phenotype despite lack of a clear selection pressure. To determine the current Xanthomonas population in Florida, we collected 585 Xanthomonas strains from 70 tomato fields, representing 22 farms across eight counties, in the Florida tomato production region. Strains were isolated from 23 cultivars across eight seed producers and were associated with eight transplant facilities during the fall 2017 season. Our collection was phenotypically and genotypically characterized. Only $X$. perforans was identified, and all strains except one (99.8\%) were tolerant to copper sulfate and $25 \%$ of strains were resistant to streptomycin sulfate. Most of the strains (99.3\%) that were resistant to streptomycin sulfate were sequence type 1 . The $X$. perforans population consisted of tomato races $3(8 \%)$ and $4(92 \%)$ and all three previously reported
\end{abstract}

ABSTRACT sequence types, ranging from 22 to $46 \%$ frequency. Approximately half of all strains, none of which were sequence type 2, produced bacteriocins against $X$. euvesicatoria. Effector profiles were highly variable among strains, which could impact the strains' host range. The effector xopJ4, which was previously thought to be conserved in $X$. perforans tomato pathogens, was absent in 19 strains. Nonmetric multidimensional scaling and network analyses show how strains and strain traits were associated with production system variables, including anonymized farms and transplant facilities. These analyses show that the composition of the Florida $X$. perforans population is diverse and complex.

Key words: antimicrobial resistance, bacterial pathogens, bacterial spot, bacteriocin, disease control, effector, epidemiology, fungicide resistance, modeling, nonmetric multidimensional scaling, pest management, pie network, streptomycin
Tomatoes are an economically important crop for the United States. In 2015, the United States' fresh market tomato harvest was valued at $>\$ 1.2$ billion. Florida is the largest producer of fresh market tomatoes in the United States, accounting for approximately one-third of total production (U.S. Department of Agriculture 2019). Florida's hot, humid climate makes tomatoes especially vulnerable to bacterial pathogens. In Florida, bacterial spot of tomato (BST) is a significant economic concern, as this disease can reduce

${ }^{\dagger}$ Corresponding authors: G. E. Vallad; gvallad@ufl.edu, and K. A. Garrett; karengarrett@ufl.edu

Current address of P. Abrahamian: Molecular Plant Pathology Laboratory, Beltsville Agricultural Research Center, U.S. Department of Agriculture Agricultural Research Service, Beltsville, MD 20705.

Funding: This research was supported by the United States Department of Agriculture National Institute of Food and Agriculture Specialty Crop Research Initiative Grants Program (2015-51181-24312), a National Science Foundation Graduate Research Fellowship (DGE-1842473), the Florida Tomato Committee Grants Program (2018-2019), and a Florida Department of Agriculture and Consumer Services Florida Specialty Crop Block Grant (00099221).

*The $e$-Xtra logo stands for "electronic extra" and indicates that supplementary figures and one supplementary table are published online.

The author(s) declare no conflict of interest.

(C) 2021 The American Phytopathological Society yield by up to $50 \%$ through foliar blighting and fruit spotting (Horvath et al. 2012; Kunwar et al. 2018; Pohronezny and Volin 1983; VanSickle and Weldon 2009). Worldwide, BST is caused by four species of Xanthomonas (X. euvesicatoria, X. gardneri, X. perforans, and $X$. vesicatoria) (Jones et al. 2004); however, only $X$. euvesicatoria and $X$. perforans have been identified in Florida (Jones et al. 1998; Timilsina et al. 2019). Barak et al. (2016) and Constantin et al. (2016) proposed consolidating X. perforans and $X$. euvesicatoria into one species, as their whole genome sequences share high average nucleotide identity. However, for this study, we will refer to these as two separate taxa, as defined by Jones et al. (2004).

Prior studies demonstrated that the Florida BST populations have shifted dramatically over the past 30 years (Horvath et al. 2012; Jones et al. 1998; Schwartz et al. 2015; Timilsina et al. 2019; Vallad et al. 2013). Prior to 1991, X. euvesicatoria was the only species isolated from Florida tomatoes; however, this changed in 1991 when $X$. perforans was first isolated and by the early 2000s had completely replaced $X$. euvesicatoria. Consequently, only $X$. perforans has been isolated from Florida tomatoes for the past 15 years. Tudor-Nelson et al. (2003) and Hert et al. (2005) revealed that this was attributable in large part to $X$. perforans' ability to produce three bacteriocins effective against $X$. euvesicatoria: BCN-A, BCN-B, and BCN-C. The first $X$. perforans strains isolated from Florida in the 1990s were tomato race 3 (T3) and members of the $X$. perforans sequence type 1 group (Jones et al. 1998; Timilsina et al. 2016, 2019). However, 
a dramatic shift in the prevalent tomato race and multilocus sequence type has occurred since that time, despite the lack of any commercially deployed resistant cultivars. In 2006, only $30 \%$ of the 377 strains collected during a statewide survey were race $\mathrm{T} 3$, whereas $70 \%$ were a new tomato race: tomato race 4 (T4) (Horvath et al. 2012). The proportion of T3:T4 strains was even lower by 2012, when only T4 strains were isolated via a statewide collection of 175 X. perforans strains (Vallad et al. 2013). A collection in 2006 revealed that strains representing two new multilocus sequence types were present in Florida in addition to the original sequence type 1 strains (Horvath et al. 2012; Schwartz et al. 2015; Timilsina et al. 2019). Among the Florida BST collections, sequence type 1 was identified in 2006 and 2012 but not in 2015/2016; sequence type 2 was isolated in Florida in 2006, 2012, and 2015/2016; and sequence type 3 was identified in 2006 and 2015/2016 but not in 2012 (Abrahamian et al. 2019b; Schwartz et al. 2015; Timilsina et al. 2019).

Current treatment strategies available to growers for BST have shown limited efficacy when conditions are conducive for disease. Copper bactericides are commonly used in field operations; however, prior studies have shown that resistance is widespread, with copper resistance observed in nearly $100 \%$ of the strains isolated during two Florida-wide surveys (Horvath et al. 2012; Vallad et al. 2013). In addition to copper, streptomycin sulfate may be applied in transplant facilities, but it is illegal to apply it in tomato fields in the United States (Abrahamian et al. 2019a). Despite prohibitions against its field application, resistance to streptomycin has increased in Florida field populations of $X$. perforans, from 5\% in 2006 to $14 \%$ in 2011 to 2012 (Horvath et al. 2012; Vallad et al. 2013).

BST-causing xanthomonads are diverse and quickly evolving throughout the world, which is thought to be why these pathogens can quickly overcome bactericide treatments and host resistance (Potnis et al. 2011, 2015; Timilsina et al. 2015). A better understanding of how the Xanthomonas pathogen is spread within the tomato production system would pinpoint where management efforts should be focused to best control and limit the spread of pathogen inoculum. Jones et al. (1986) concluded that primary sources of Xanthomonas inoculum in Florida were likely volunteer tomato plants as well as crop residue from the previous season, in those occasions where the initial crop was grown in the fall and the successive crop was planted the following spring, whereas tomato seeds and nearby weeds were unlikely sources. In contrast, Sijam et al. (1991) detected pathogenic Xanthomonas from 15 of 22 tomato seed lots that were washed and plated on a selective medium. The dramatic population shifts over relatively short time periods suggest that the pathogen does not originate solely from volunteer tomato plants and/or crop residue within the field. Other studies have highlighted the importance and rapid spread of Xanthomonas pathogens within transplant production facilities (Abrahamian et al. 2019b, 2021) and support the hypothesis described by Jones et al. (1986) that bacterial populations within or around the field may provide inoculum to field plants. There are many different sources of inoculum in the tomato production system; however, the relative contribution of each source is unknown at this time.

In this study, our objective was to test for associations among strain traits, and between strain traits and tomato production system variables, to identify possible routes of spread throughout the tomato production system and factors responsible for population shifts. We collected BST-causing Xanthomonas strains from fresh market tomato production fields across Florida and southern Georgia and characterized all strains for several phenotypic and genotypic traits, including Xanthomonas species, streptomycin resistance, copper tolerance, bacteriocin production, tomato race, pepper and tomato pathogenicity, $X$. perforans sequence type, and presence or absence of four effectors. For each strain, we evaluated metadata consisting of production system variables based on the production history of the plant each strain was isolated from, as well as producer information. Production system variables included specifics for farm and grower operation where the plants were located, tomato cultivar and seed producer information, as well as information on the transplant facility where the plants were originally sown and grown. We evaluated the association between production system variables and phenotypic and genotypic traits using nonmetric multidimensional scaling (NMDS). Specific farm and transplant facility information were anonymized for presentation.

\section{MATERIALS AND METHODS}

Sample collection. Symptomatic tomato leaf, fruit, and stem samples were collected during the fall 2017 growing season. Fields were scouted in a zigzag pattern, collecting samples (range, 2 to 20) arbitrarily while crossing each 4 - to 16-ha field. The entire collection consisted of strains isolated from 70 fresh market commercial tomato fields (range, 2 to 12 strains per field) across Florida and southern Georgia, totaling 22 different farms across eight counties. Tomato production system variables, including field, farm, county, region, grower operation, transplant facility, cultivar, and seed producer, were recorded for each sample. A unique value of 1 to 70 was assigned to each field in the collection. To visualize the locations of sampled farms, as well as the transplant facilities where plants were sown and grown, the ggplot function from the R package tidyverse

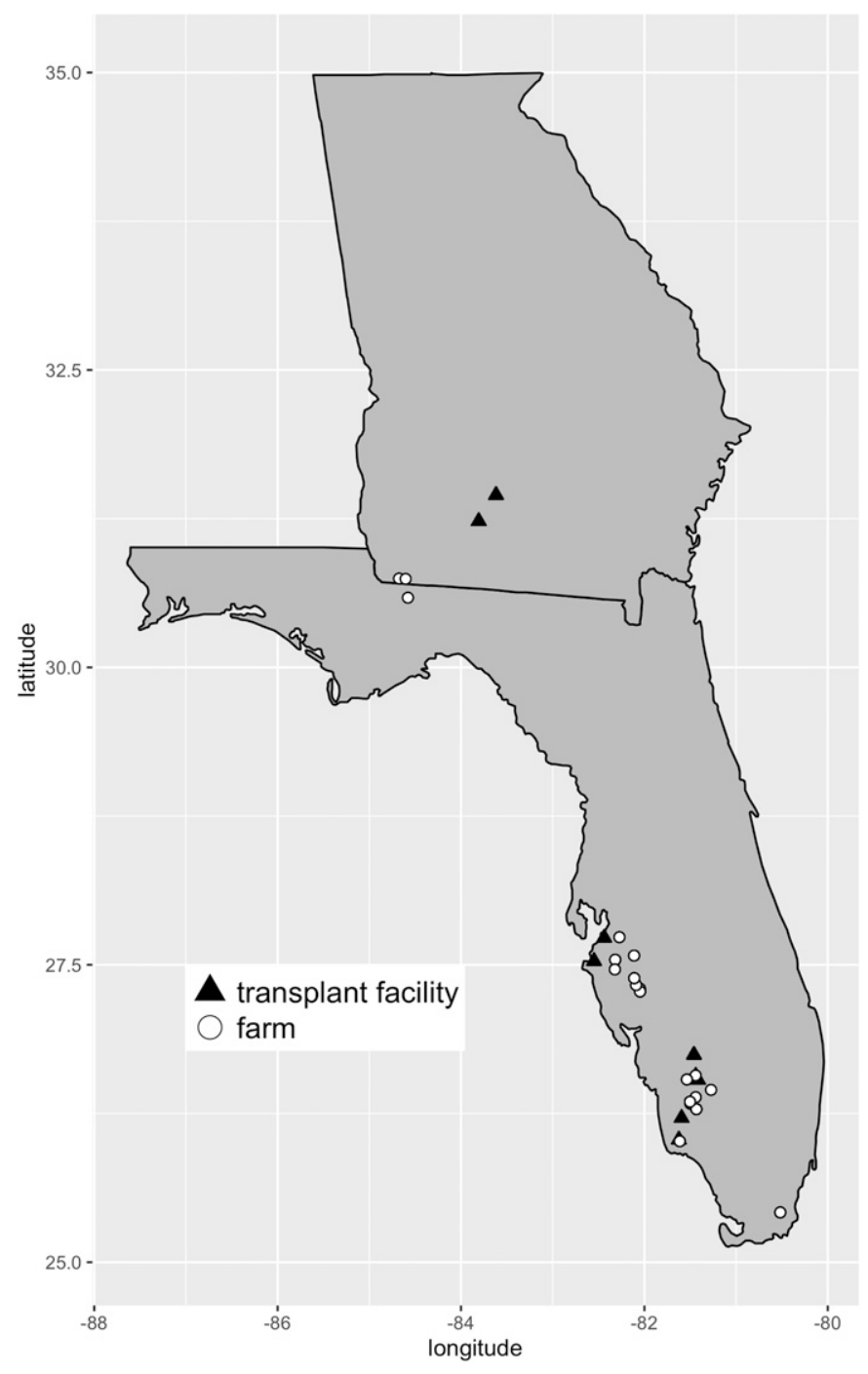

Fig. 1. Map of Florida and Georgia showing farm locations where tomato plants were sampled for bacterial spot and transplant facilities that supplied the tomato seedlings for the farms. 
(R Core Team 2020; Wickham et al. 2019) was used to plot a map (Fig. 1) based on GPS coordinates of those locations.

Bacterial strains and isolations. For leaf samples, a sterile inoculation needle with an angled tip, wetted with sterile tap water, was pierced through a single lesion and moved back and forth through the lesion. The inoculation needle was then placed, with the bevel face down, on the surface of nutrient agar (NA) medium (BBL; Becton Dickinson and Co., Franklin Lakes, NJ) and gently stroked across the agar surface in a standard streak pattern. For fruit and stem samples, a single lesion was excised and macerated in sterile tap water, then this liquid was streaked on NA using a standard inoculation loop. Plates were incubated for 72 to $96 \mathrm{~h}$ at $28^{\circ} \mathrm{C}$ until individual, yellow bacterial colonies were observed. To ensure one cell type was isolated, one colony was selected per Petri plate, restreaked on a NA plate, and incubated an additional 72 to $96 \mathrm{~h}$ at $28^{\circ} \mathrm{C}$. A single colony from this second isolation was then restreaked on NA and incubated at $28^{\circ} \mathrm{C}$ for $24 \mathrm{~h}$. Prior to storage, species identity was confirmed using the $h r c N$ locus with real-time PCR, as described by Strayer et al. (2016). Briefly, cells grown on NA for $24 \mathrm{~h}$ were boiled in sterile tap water for $20 \mathrm{~min}$, then $2 \mu \mathrm{l}$ of the boiled-cell supernatant was used as the DNA template in the multiplex real-time TaqMan PCR assay, using $X$. euvesicatoria strain E3-1, X. gardneri strain $444, X$. perforans strain 91-118, and $X$. vesicatoria strain MME as species controls (Table 1). Once strain identity was confirmed as one of the four species of Xanthomonas causing bacterial leaf spot on tomato, cultures were assigned a strain name and stored in nutrient broth with $30 \%$ glycerol at $-80^{\circ} \mathrm{C}$. A list of all 585 Xanthomonas strains isolated in this study, with the associated tomato production system variables, is provided in Supplementary Table S1. All strains that were previously reported and used as controls within this study are listed in Table 1.

Phenotype assays. All 585 strains were characterized for all phenotypic traits. For each assay, Xanthomonas strains were cultured overnight on NA amended with $20 \mu \mathrm{g} / \mathrm{ml}$ of copper sulfate pentahydrate (J. T. Baker Chemical Company, Phillipsburg, NJ) at $28^{\circ} \mathrm{C}$. Cells were removed from the Petri plate and suspended in sterile tap water at a cell density of $\mathrm{OD}_{600}$ of $0.3\left(10^{8} \mathrm{CFU} / \mathrm{ml}\right)$. Because of the high quantity of strains tested, each test was performed once per strain with the specified number of replicates per strain, unless results varied between replicates or an unexpected phenotype was

TABLE 1. Previously described bacterial strains used as controls in this study

\begin{tabular}{|c|c|c|}
\hline Strain & Relevant characteristics $^{\mathrm{a}}$ & Reference \\
\hline $\begin{array}{l}\text { Xanthomonas } \\
\text { euvesicatoria E3-1 }\end{array}$ & $\mathrm{T} 1, \mathrm{Cop}^{\mathrm{r}}, \mathrm{Sm}^{\mathrm{r}}$, amylase ${ }^{-}$ & Hert et al. (2009) \\
\hline $\begin{array}{l}X . \text { euvesicatoria } \\
91-106\end{array}$ & $\begin{array}{c}\mathrm{BCN}-\mathrm{A}^{\mathrm{s}}, \mathrm{BCN}-\mathrm{B}^{\mathrm{s}}, \\
\text { BCN-C } \mathrm{Km}^{\mathrm{s}}\end{array}$ & $\begin{array}{l}\text { Tudor-Nelson et al. } \\
\text { (2003) }\end{array}$ \\
\hline $\begin{array}{l}\text { X. euvesicatoria } \\
91-106 \mathrm{~K}\end{array}$ & 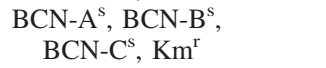 & Klein et al. (2020) \\
\hline X. gardneri 444 & & $\begin{array}{l}\text { Astua-Monge et al. } \\
\quad(2000 \mathrm{a})\end{array}$ \\
\hline X. perforans $91-118$ & 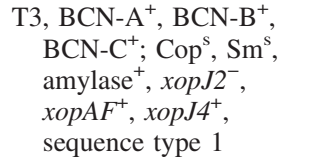 & $\begin{array}{l}\text { Tudor-Nelson et al. } \\
\text { (2003) }\end{array}$ \\
\hline X. vesicatoria MME & - & $\begin{array}{l}\text { Astua-Monge et al. } \\
\quad(2000 \mathrm{a})\end{array}$ \\
\hline X. perforans GEV839 & 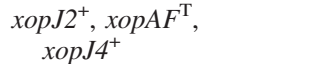 & $\begin{array}{l}\text { Timilsina et al. } \\
(2015)\end{array}$ \\
\hline X. perforans GEV 2010 & 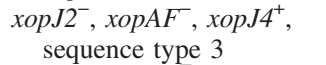 & $\begin{array}{l}\text { Abrahamian et al. } \\
\text { (2019b) }\end{array}$ \\
\hline X. perforans Xp2010 & $\begin{array}{l}\text { xоpJ2 } 2^{-}, \text {хорАF } F^{\mathrm{T}}, \text { xopJ4 }^{-}, \\
\text {sequence type } 2\end{array}$ & $\begin{array}{l}\text { Schwartz et al. } \\
\quad(2015)\end{array}$ \\
\hline
\end{tabular}

${ }^{a}$ Plus and minus signs indicate the presence and absence of gene or protein production, respectively. Superscript letters indicate the following: $r=$ resistant to compound, $\mathrm{s}=$ sensitive to compound, and $\mathrm{T}=$ transposon insertion present within amplified gene sequence. $\mathrm{T} 1=$ tomato race 1 , Cop $=$ copper, $\mathrm{Sm}=$ streptomycin, $\mathrm{BCN}=$ bacteriocin, $\mathrm{Km}=$ kanamycin, and $\mathrm{T} 3=$ tomato race 3 . observed. Colony pigmentation was documented before strain storage based on color relative to $X$. perforans 91-118.

Copper sensitivity, streptomycin sensitivity, and amylase production. Copper and streptomycin sensitivity were determined by plating $5 \mu \mathrm{l}$ of the cell suspension on three replicate NA plates amended with $200 \mu \mathrm{g} / \mathrm{ml}$ of copper sulfate or $200 \mu \mathrm{g} / \mathrm{ml}$ of streptomycin sulfate (Sigma-Aldrich, St. Louis, MO), respectively. Twelve test strains, in addition to a positive and negative control, were inoculated per Petri plate in a grid pattern, with three replicate plates per strain. Petri plates were incubated for $24 \mathrm{~h}$ at $28^{\circ} \mathrm{C}$ and resistance was confirmed as a lawn of growth where the cell suspension droplet was originally placed. Amylolytic activity, which was reported by Jones et al. (2004) as indicative of BST species X. perforans and X. vesicatoria, was determined by plating $5 \mu \mathrm{l}$ of the cell suspension on three replicate NA plates amended with $1.5 \%$ potato starch in the same grid pattern as antibiotic and copper assays, with controls present on each Petri plate. Petri plates were incubated for $24 \mathrm{~h}$ at $28^{\circ} \mathrm{C}$ and amylase production was confirmed as a cloudy halo surrounding lawn of growth. X. euvesicatoria E3-1 (copper resistant, streptomycin resistant, absence of amylase production) and $X$. perforans 91-118 (copper sensitive, streptomycin sensitive, presence of amylase production) were used as control strains for each assay.

Bacteriocin production. The deferred antagonism assay, which is described in detail by Klein et al. (2020), was used to detect bacteriocin production for $X$. perforans and $X$. euvesicatoria, with plastic Petri plates. Each strain was tested with two replicates. $X$. euvesicatoria $91-106 \mathrm{~K}$, a kanamycin-resistant strain, was used as the indicator strain for all tests, and $X$. perforans 91-118 and X. euvesicatoria 91-106 were used as the positive and negative control strains, respectively.

Pathogenicity and tomato race determinations. Pathogenicity on pepper and tomato, as well as tomato race, was determined using the criteria described by Stall et al. (2009). To determine pathogenicity, bacterial suspensions were infiltrated into the susceptible tomato cultivar Bonnie Best and susceptible pepper cultivar Early Calwonder (ECW). For tomato, strains that did not elicit a hypersensitive response (HR) within $48 \mathrm{~h}$ after inoculation, but elicited necrosis in the area of inoculation within 72 to $96 \mathrm{~h}$, were recorded as pathogenic. For pepper, areas of inoculation were monitored for $48 \mathrm{~h}$ postinoculation, and the presence of a strong HR, weak HR, or water-soaking response was recorded. For tomato race determination, bacterial suspensions were infiltrated into tomato genotypes Hawaii 7998 with the $r x v$ resistance gene and FL 216 with the $X v 3$ resistance gene. Tomato race 1 (T1) strains were expected to elicit an HR on Hawaii 7998 and a water-soaking response and subsequent necrosis on FL 21672 to $96 \mathrm{~h}$ postinoculation. T3 strains were expected to elicit an HR on FL 216 in the inoculated area between 24 and 48 $\mathrm{h}$ after inoculation, and T4 strains were observed as eliciting a water-soaking response and subsequent necrosis in the area of inoculation on FL 21672 to $96 \mathrm{~h}$ postinoculation. Each strain was infiltrated into a distinct section of one leaf or leaflet across three different plants. X. euvesicatoria E3-1 (T1) and X. perforans 91-118 (T3) were used as control strains.

Genetic characterization assays. All 585 strains were characterized for genotype. For each assay, $2 \mu \mathrm{l}$ of the previously described boiled-cell DNA extraction was used per PCR reaction.

$\mathrm{X}$. perforans sequence type determination. Sequence types were determined based on the Florida $X$. perforans population groupings defined by Timilsina et al. (2019). Primers were developed to amplify parts of the septum formation protein maf (AQS76051.1) and the ABC transporter ATP-binding protein $m d l B$ (AQS75548.1). Timilsina et al. (2019) determined that maf could distinguish between the three sequence types of $X$. perforans based on core genome multilocus sequence typing (Timilsina et al. 2019). The gene $m d l B$ showed consistent nucleotide variation by sequence type in a different set of 103 X. perforans genomes (Abrahamian et al. 2019b). Both genes 
were used for differentiating the sequence types. PCR reactions were confirmed for the presence of the expected amplicon for each gene with gel electrophoresis, then submitted to GENEWIZ (South Plainfield, NJ) for Sanger sequencing, using the Sep1-R and SubC1-F primers (Table 2) for the maf and $m d l B$ sequencing outputs, respectively. Resulting sequences were trimmed, then MUSCLE alignments were performed within Geneious 2019.0.2 (https://www.geneious.com) to identify distinguishing single nucleotide polymorphisms (SNPs) (Edgar 2004). A sequence from one reference strain from each described sequence type (1,X. perforans $91-118 ; 2, X$. perforans Xp2010; and 3, X. perforans GEV2010) was used for comparison. To generate a summary graphic showing SNPs among sequence type for each gene, representative sequences were aligned with T-Coffee (Notredame et al. 2000), then the alignment was input into BOXSHADE (ExPASy; Swiss Institute of Bioinformatics, Lausanne, Switzerland) and subsequent output was manually modified.

Effector determination. The presence or absence of four type III secretion system effectors, xopJ4 (avrXv4), xopJ2 (avrBsT), xopAF $(a v r X v 3)$, and a $x o p J 2$ homolog, was determined with a multiplex PCR assay, using different amplicon lengths as detailed in Table 2. GoTaq Green MasterMix (Promega, Madison, WI) was supplemented with primer sets for each of the four genes (final concentration of $0.16 \mu \mathrm{M}$ per primer) and boiled-cell DNA extraction and brought to a final volume of $25 \mu \mathrm{l}$ with RNase-free water. PCR cycling parameters were as follows: (i) $95^{\circ} \mathrm{C}$ for $3 \mathrm{~min}$, (ii) $95^{\circ} \mathrm{C}$ for $30 \mathrm{~s}$, (iii) $55^{\circ} \mathrm{C}$ for $30 \mathrm{~s}$, (iv) $72^{\circ} \mathrm{C}$ for $80 \mathrm{~s}$, (v) repeat steps ii through iv 30 times, (vi) $72^{\circ} \mathrm{C}$ for $3 \mathrm{~min}$, and (vii) $10^{\circ} \mathrm{C}$ indefinitely. $X$. perforans strains 91-118, GEV839, GEV2010, and Xp2010 were used as control strains for effector presence and absence. The presence or absence of each effector was determined by visually checking the subsequent gel electrophoresis image for the presence of an amplicon of expected length as compared with control strains included with each gel and PCR reaction. Strains for which no amplicons were detected for any of the four genes were retested; upon confirming that no amplicons were present in the second attempt, DNA extraction quality was verified with amplification of conserved sequences using the sequence type determination assay above.

The $x o p A F$ gene has been reported to have several allele types with various types of deleterious mutations, including a nonsense mutation, truncation of the gene, and transposon insertion (Timilsina et al. 2016). X. perforans strains GEV839 and Xp2010, which each contain transposon insertions of approximately 1,200 nt within $x o p A F$, were used to screen for the presence of a similar transposon insertion in test strains (Timilsina et al. 2016). The xopAF primers used in this study surround the region with the known insertion, so the amplicon for $x о p A F$ appears as approximately 1,200 nt longer for strains containing this insertion sequence. The $x o p A F$ gene was extracted from unpublished whole genome sequences of 281 strains within this collection and analyzed with NCBI BLAST (Altschul et al. 1990) to confirm the presence of the insertion sequence and to identify the presence of the known nonsense mutation and/or any additional mutations in the gene.

Comparison of sequence type relative abundance. The relative proportion of sequence types across all fields was evaluated. Abundance proportions for each sequence type were input into the eulerAPE version 3 program (Micallef and Rodgers 2014) and run with default settings, specifying ellipse curve output in a Venn diagram. Colors were added to the output diagram manually with the GIMP version 2.10.20 image manipulation program (The GIMP Team).

Network analyses. We evaluated how sequence type and streptomycin resistance were partitioned across the hierarchy of plant history variables, following the tomato production system across transplant facility, farm, and field, as well as tomato cultivar, all of which were anonymized. The system analysis was plotted using the $\mathrm{R}$ package igraph (Csardi and Nepusz 2006) and custom scripts to incorporate pie charts indicating the proportion of traits observed at each level (R Core Team 2020). For analysis of sequence type, all 585 strains were evaluated; for streptomycin resistance, only sequence type 1 strains were evaluated (188 strains). For each of the two networks, the node representing each category of a production system variable was presented as a pie chart with the proportion of sequence type 1 , sequence type 2 , and sequence type 3 strains, or with the proportion of streptomycin-resistant versus streptomycinsensitive strains. The node size indicated the relative number of strains within each plant history variable, except for the field variable for which the same node size was assigned for all fields. Links between hierarchical variable categories were constructed based on the observed production system paths for distribution of plant materials.

NMDS analyses. NMDS was applied for ordination of all 585 strains by their nine characterization variables (xopJ2, xopJ2 homo$\log$, xорJ4, sequence type 1 , sequence type 2 , sequence type 3 , tomato race, bacteriocin production, and streptomycin sulfate resistance), which condensed the strains' characterization information into a two-dimensional (2D) ordination space. We used the NMDS function metaMDS from the R package vegan (Oksanen et al. 2019; R Core Team 2020) with minimum and maximum numbers of random starts of 30 and 100, respectively, and monoMDS (monotone regression) as the engine argument. The more similar the strains, the closer the strains are located in the ordination space, and strains with the same genetic traits will distribute in the same location on a 2D ordination space plot. Functions ordiplot and ordiellipse from the vegan package (Oksanen et al. 2019) were used to plot ellipses to delineate strains based on production system variables in the ordination space.

TABLE 2. Primers designed and used in this study

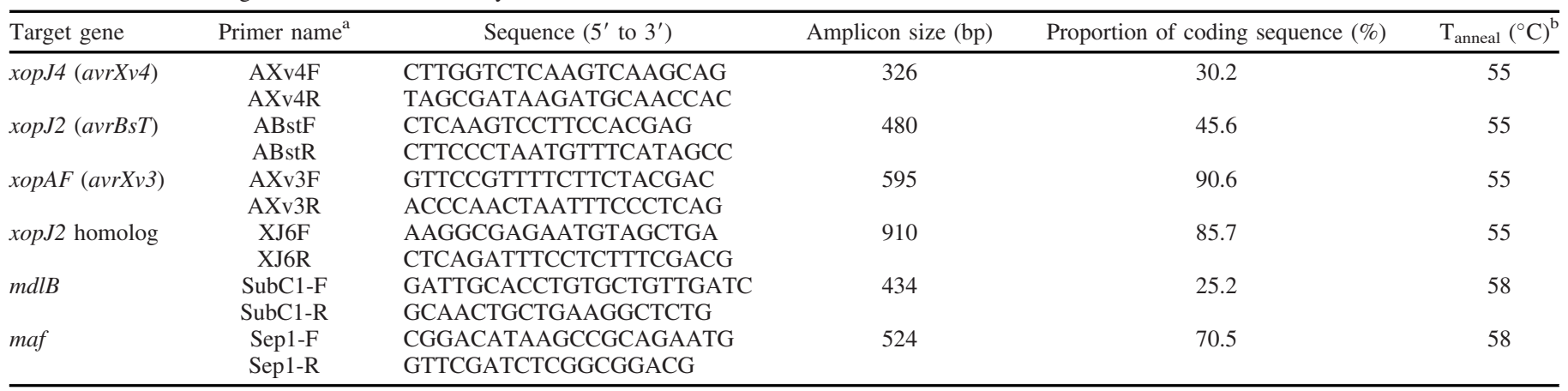

${ }^{\mathrm{a}} \mathrm{F}=$ forward and $\mathrm{R}=$ reverse.

${ }^{\mathrm{b}} \mathrm{T}_{\text {anneal }}=$ annealing temperature. 


\section{RESULTS}

Overall collection. Tomato samples were collected from plants that represented a variety of tomato production system variables across Florida and southern Georgia. Geographic distribution of farms and transplant facilities from which transplants originated are shown in Figure 1. Farm locations visually cluster into regions designated as Northwest, Central-West, Southwest, and Southeast regions. Sampled plants represented 23 different cultivars of round $(n=11)$, plum $(n=10)$, grape $(n=1)$, and cherry $(n=1)$ tomato types, produced by eight seed companies. A total of 585 strains were isolated: 552 from leaves, 31 from fruit, and two from stem tissue. All strains were identified as $X$. perforans using the $h r c N$ locus and further confirmed via amylase activity. Phenotypic and genotypic characterization results for each strain, along with production system variables, are available in Supplementary Table S1. Table 3 displays a summary of characterization results, including the number and proportion of strains of each sequence type for phenotypes and genotypes tested.

Sequence type identities. Alignment of amplified portions of $m d l B$ and maf revealed that 188 strains, or $32.1 \%$ of the total population, were sequence type 1 . Sequence type 2 represented $45.7 \%$ of the total population, or 267 strains. Sequence type 3 represented the lowest portion of the population, with 130 strains, or $22.2 \%$ of all strains. All 585 strains had $100 \%$ identity to one of the three reference sequence types for both genes. Five SNPs differentiated sequence type 1 from sequence type 2 for $m a f$ and 15 for $m d l B$, and sequence type 3 differed from sequence type 1 by 15 SNPs for maf and 10 for $m d l B$ (Supplementary Figs. S1 and S2). We found that 25\% of the 70 sampled fields contained a single sequence type, and $16 \%$ of fields contained all three sequence types (Fig. 2).

In vitro phenotypic characterization. Twenty-seven strains had a distinct lighter yellow colony color when grown on NA compared with the standard yellow coloration of $X$. perforans strain 91-118 and the other 558 strains (Supplementary Fig. S3). Of 585 strains, only one was sensitive to copper sulfate at $200 \mu \mathrm{g} / \mathrm{ml}$. Streptomycin resistance was less prevalent than copper tolerance, with 144 strains, or $24.6 \%$ of the total population, showing resistance to streptomycin sulfate at $200 \mu \mathrm{g} / \mathrm{ml}$. Most of the strains (99.3\%) that were resistant to streptomycin were sequence type 1 . Bacteriocin activity against the indicator strain X. euvesicatoria $91-106 \mathrm{~K}$ was observed with 298 strains, or $50.9 \%$ of the total population. Sixty-two fields, or $88.6 \%$ of sampled fields, contained at least one strain capable of bacteriocin production. None of the sequence type 2 strains produced bacteriocins, whereas 98.4 and $86.9 \%$ of the sequence type 1 and 3 strains, respectively, produced bacteriocins. Of the 298 bacteriocinproducing strains, 282 produced large zones of inhibition (radius between 6 and $7.75 \mathrm{~mm}$ outside the producer colony) similar to those of $X$. perforans 91-118, 15 produced medium zones of inhibition (radius between at least 3 and $<6 \mathrm{~mm}$ ), and one strain produced a small zone of inhibition (radius $<3 \mathrm{~mm}$ ).

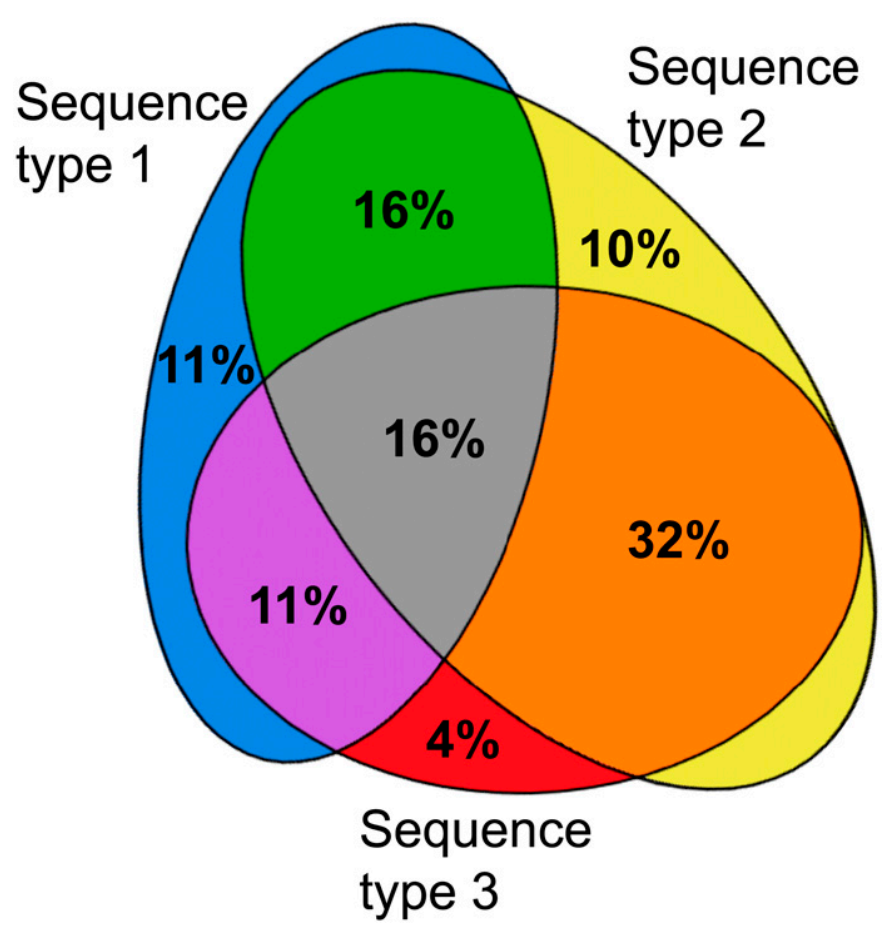

Fig. 2. Venn diagram of sequence type composition in each field across 70 fields. Strains from each field were assigned to sequence types 1, 2, or 3 using unique single nucleotide polymorphisms from genes maf and $m d l B$. Percentages indicate the number of fields with each possible combination of sequence type out of the 70 total fields. Fields containing only sequence type 1 strains comprised $11 \%$ of all fields sampled, $10 \%$ of fields had only sequence type 2 , and $4 \%$ had only sequence type 3 . Overlapping areas of ellipses indicate fields that contained multiple sequence types.

TABLE 3. Sequence type relative to phenotype and genotype

\begin{tabular}{|c|c|c|c|c|}
\hline \multirow[b]{2}{*}{ Phenotype/genotype } & \multicolumn{4}{|c|}{ Number of strains ( $\%$ of sequence type) } \\
\hline & All strains ${ }^{\mathrm{a}}$ & Sequence type 1 & Sequence type 2 & Sequence type 3 \\
\hline Copper sulfate resistance ${ }^{b}$ & $584(99.8)$ & $188(100)$ & $266(99.6)$ & $130(100)$ \\
\hline Streptomycin sulfate resistance ${ }^{b}$ & $144(24.6)$ & $143(76.1)$ & $1(0.4)$ & $0(0)$ \\
\hline Lighter yellow colony color & $27(4.6)$ & $26(13.8)$ & $1(0.4)$ & $0(0)$ \\
\hline Bacteriocin production $^{c}$ & $298(50.9)$ & $185(98.4)$ & $0(0)$ & $113(86.9)$ \\
\hline Large & $282(48.2)$ & $173(92.0)$ & $0(0)$ & $109(83.8)$ \\
\hline Medium & $15(2.6)$ & $11(5.9)$ & $0(0)$ & $4(3.1)$ \\
\hline Small & $1(0.2)$ & $1(0.5)$ & $0(0)$ & $0(0)$ \\
\hline Tomato race $\mathrm{T} 3$ & $49(8.4)$ & $38(20.2)$ & $1(0.4)$ & $10(7.7)$ \\
\hline $\begin{array}{l}\text { Hypersensitive response on pepper } \\
\text { cultivar Early Calwonder }\end{array}$ & $530(90.6)$ & $185(98.4)$ & $252(94.4)$ & $93(71.5)$ \\
\hline xopJ $2^{+}$ & $432(73.8)$ & $181(96.3)$ & $251(94.0)$ & $0(0)$ \\
\hline xopJ2 homolog ${ }^{+}$ & $84(14.4)$ & $0(0)$ & $0(0)$ & $84(64.6)$ \\
\hline xopJ4 $4^{+}$ & $566(96.8)$ & $186(98.9)$ & $252(94.4)$ & $128(98.5)$ \\
\hline$x о p A F^{+}$ & $204(34.9)$ & $183(97.3)$ & $0(0)$ & $21(16.2)$ \\
\hline$x o p A F^{\mathrm{T}+\mathrm{d}}$ & $207(35.4)$ & $3(1.6)$ & $204(76.4)$ & $0(0)$ \\
\hline
\end{tabular}

a There were 585 total strains: 188 strains comprised sequence type 1, 267 strains comprised sequence type 2 , and 130 strains comprised sequence type 3.

b Able to grow on nutrient agar amended with $200 \mu \mathrm{g} / \mathrm{ml}$ of copper sulfate or streptomycin sulfate.

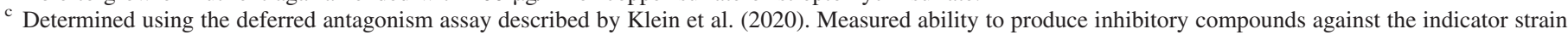
Xanthomonas euvesicatoria 91-106K. Large zones were defined as an inhibition zone with a radius between 6 and 7.75 mm outside the producer colony, medium zones as an inhibition zone with a radius between at least 3 to $<6 \mathrm{~mm}$, and small zones as an inhibition zone with a radius $<3$ mm.

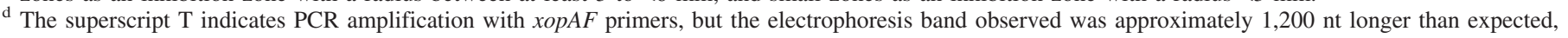
presumably owing to a transposon insertion sequence. 
Pathogenicity and race determination. All strains were pathogenic on tomato, with 49 strains, or $8.4 \%$ of the total population, identified as T3 and 536 strains, or $91.6 \%$ of the total population, as T4. Most of the T3 strains (77.6\%) were sequence type 1. Most strains did not appear to be pathogenic on pepper, as 530 strains, or $90.6 \%$ of the total population, elicited some degree of HR on susceptible pepper cultivar ECW within $48 \mathrm{~h}$ of infiltration. However, 13 strains elicited the typical HR of confluent necrosis, as nonpepper-pathogenic $X$. perforans strain 91-118 did, whereas 517 strains elicited an atypical, weaker HR that did not display confluent necrosis. Atypical HR plant symptoms ranged from varying degrees of predominant necrosis around edges of the area of inoculation with little to no necrosis and tissue collapse in the center, and a mottled appearance of necrosis and tissue collapse for the entire area of inoculation. All 13 strains that elicited a typical HR were sequence type 1, the same sequence type as $X$. perforans strain 91-118. The 55 strains that did not elicit an HR on pepper were examined further on standard pepper lines to determine pepper race (Stall et al. 2009); however, atypical symptoms were observed when compared with typical symptoms caused by known Xanthomonas pepper pathogens. Most pepper differentials displayed a water-soaked appearance from 24 to $48 \mathrm{~h}$ postinoculation when infiltrated at $10^{8} \mathrm{CFU} / \mathrm{ml}$ of $X$. perforans, whereas infiltration of lower cell concentrations into leaves was inconclusive for determining whether strains were pathogenic. Of the 55 strains hypothesized to be pathogenic on pepper, most $(67.3 \%)$ were sequence type 3 .

Effector content variation. Effector profiles varied between strains for type III secretion system effectors xopJ4 (avrXv4), xopJ2 (avrBsT), xopAF (avrXv3), and a xopJ2 homolog based on PCR amplification of parts of these genes. Table 4 summarizes effector profiles identified in this study and the associated sequence types and tomato races for each profile. Thirteen unique combinations of amplicon presence or absence were identified across four effector genes and the $x о p A F$ variant with the transposon insertion. Nineteen strains did not appear to have xopJ4, whereas 566 strains, or $96.8 \%$ of the total population, contained the gene for this effector. The effector xopJ 2 gene was present in 432 strains, or $73.8 \%$ of the total population, all of which were within sequence types 1 and 2. The xopJ2 homolog was present in 84 strains, or $14.4 \%$ of the total population, all of which were sequence type 3. XopJ2 and the xopJ2 homolog were not observed together in any strain. The xopJ2 homolog results agree with previous studies in which identification of this homolog was first reported (Abrahamian 2017; Iruegas-Bocardo et al. 2018).

Amplicon presence and absence via our multiplex PCR assay revealed that 207 strains contained an approximately 1,200-bp insertion sequence within $x o p A F, 204$ strains contained $x o p A F$, and 174 strains lacked $x o p A F$. Sequences of $x o p A F$ extracted from whole genome sequences of a subset of 281 strains from this collection (unpublished results) confirmed PCR amplification results. Ninetyfive strains that lacked an amplicon did not contain $x o p A F$ in the genome sequence, 98 strains that produced a longer amplicon contained an insertion sequence within $x o p A F$, and 88 strains that were expected to contain $x o p A F$ had either $100 \%$ identity (38 strains) or one of two SNP variations. Forty of the 88 strains encoded a SNP in the 205th nucleotide, from cytosine to thymine, that encodes for a premature stop codon, as reported in a previous study (Timilsina et al. 2016). Ten of the 88 strains encoded two SNPs that have not been previously reported, resulting in a change in two amino acids (i.e., L50P and V182L).

Effector content was compared with tomato race. Of the 49 strains phenotypically identified as race T3, 36 were confirmed via sequencing to have $100 \%$ nucleotide identity to $x o p A F$, five strains were confirmed via sequencing to encode for two amino acid substitutions in $x o p A F$, six strains were confirmed via PCR amplification but not sequencing to have $x o p A F$, one strain was confirmed via PCR amplification and sequencing to not contain $x o p A F$, and one strain appeared to contain a transposon insertion based on PCR amplification but was not sequenced. Five race T4 strains contained the same two amino acid substitutions within $x o p A F$ as five of the race T3 strains. Also, two strains with $100 \%$ sequence identity to $x o p A F$ were phenotypically characterized as race $\mathrm{T} 4$.

Effector content was compared with pepper pathogenicity. All 432 strains that contained xopJ2 elicited some level of an HR when infiltrated into pepper. Eighty-four strains contained the xopJ2 homolog, of which 82 strains elicited an HR in pepper. Sixty-nine strains did not contain either xopJ 2 or the xopJ 2 homolog, of which 53 did not elicit an HR on pepper, as expected, whereas 16 strains did. Ten of the 16 HR-eliciting strains contained $x o p A F$.

Tomato production system networks in Florida. The network illustrating the hierarchy of tomato production variables demonstrates the complexity of the fresh market tomato industry in Florida (Fig. 3). Eighty-eight percent of transplant facilities sowed and grew between 2 to 11 tomato cultivars for two to six farms. Eighty-six percent of farms obtained their transplants from a single transplant facility, although three farms obtained transplants from multiple transplant facilities. A single field of tomatoes within a farm contained the same cultivar, which was obtained from a single transplant facility. In general, most farms, transplant facilities, and cultivars were associated with more than one $X$. perforans sequence type (Fig. 3; Table 5). Also, nodes that were associated with two or three sequence types tended to be those represented by higher numbers of strains (so that the greater observed diversity can be attributed in part to greater sampling effort) and/or associated with a higher number of upstream nodes. The network was reconstructed for sequence type 1 strains to examine the distribution of resistance to streptomycin sulfate at $200 \mu \mathrm{g} / \mathrm{ml}$ among nodes (Fig. 4; Table 6). Nodes that completely lacked streptomycin-resistant sequence type 1 strains were less common than nodes with some degree of streptomycin-resistant sequence type 1 strains.

NMDS analyses. The NMDS stress goodness-of-fit was 0.028 , suggesting a good fit to the data. As expected, previously described associations between strain characterizations were also observed in

TABLE 4. Effector profile diversity across sequence types and tomato races, identified as the presence or absence of PCR amplicons via gel electrophoresis

\begin{tabular}{|c|c|c|c|c|c|c|c|c|c|c|c|c|c|}
\hline Effector profile & 1 & 2 & 3 & 4 & 5 & 6 & 7 & 8 & 9 & 10 & 11 & 12 & 13 \\
\hline xорJ4 & $+{ }^{\mathrm{a}}$ & + & + & + & + & + & + & + & - & - & - & - & - \\
\hline хорАF & - & + & - & - & - & - & + & + & - & - & + & - & - \\
\hline xорJ2 & + & + & - & + & - & - & - & - & + & + & + & - & - \\
\hline xopJ2 homolog & - & - & + & - & - & - & + & - & - & - & - & - & - \\
\hline$x о p A F^{\mathrm{Tb}}$ & + & - & - & - & - & + & - & - & + & - & - & + & - \\
\hline \multicolumn{14}{|c|}{$\begin{array}{l}\text { Strain information for each } \\
\text { effector profile }(n)\end{array}$} \\
\hline Strains & 179 & 177 & 69 & 61 & 39 & 16 & 15 & 10 & 10 & 3 & 2 & 2 & 2 \\
\hline Sequence type(s) & 2 & 1 & 3 & 1,2 & 2,3 & 1,2 & 3 & 1,3 & 2 & 2 & 1 & 2 & 3 \\
\hline Tomato race(s) & 4 & 3,4 & 4 & 4 & 3,4 & 4 & 3,4 & 3,4 & 3,4 & 4 & 4 & 4 & 4 \\
\hline
\end{tabular}

${ }^{a}$ Plus and minus signs indicate presence and absence, respectively.

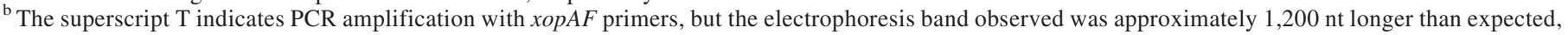
presumably attributable to a transposon insertion sequence that renders the gene nonfunctional, as reported in a previous study (Timilsina et al. 2016). 
the NMDS ordination space (Fig. 5). For example, associations were observed between streptomycin resistance and the sequence type 1 genotype, the xopJ 2 homolog and the sequence type 3 genotype, xopJ 2 and the sequence type 1 and 2 genotypes, and bacteriocin production and sequence type 1 and 3 genotypes. In addition, strains with xopJ4 and the phenotype tomato race were associated with all three sequence types; therefore, those characterization variables were located toward the center of the NMDS plot (Fig. 5). Most of the sequence type 2 strains were identical for the variables included in the NMDS analysis, so 238 of 266 sequence type 2 strains $(89.5 \%)$ were represented as the same point (Fig. 5). Similarly, most of the sequence type 1 strains had identical characterization data, so 135 of 188 sequence type 1 strains $(71.8 \%)$ were represented as the same point in Figure 5. Sequence type 3 strains appeared more phenotypically diverse than sequence type 1 and 2 strains, although the largest two points within the sequence type 3 portion of the NMDS plot represented $70(53.8 \%)$ and $36(27.7 \%)$ strains (Fig. 5).

We also considered in more detail farms and transplant facilities that were associated with $\geq 20$ strains each (Figs. 6 and 7). Six of

TABLE 5. Sequence type diversity across tomato production system variables within the collection

\begin{tabular}{lccc}
\hline & \multicolumn{3}{c}{ Number of categories (\% of total categories) } \\
\cline { 2 - 4 } Tomato production & $\begin{array}{c}\text { 1 sequence type } \\
\text { present }\end{array}$ & $\begin{array}{c}2 \text { sequence types } \\
\text { present }\end{array}$ & $\begin{array}{c}3 \text { sequence types } \\
\text { present }\end{array}$ \\
\hline Field & $18(25.7)$ & $41(58.6)$ & $11(15.7)$ \\
Farm & $4(18.2)$ & $11(50.0)$ & $7(31.8)$ \\
Transplant facility & $0(0)$ & $2(25.0)$ & $6(75.0)$ \\
Cultivar & $4(17.4)$ & $11(47.8)$ & $8(34.8)$ \\
\hline
\end{tabular}

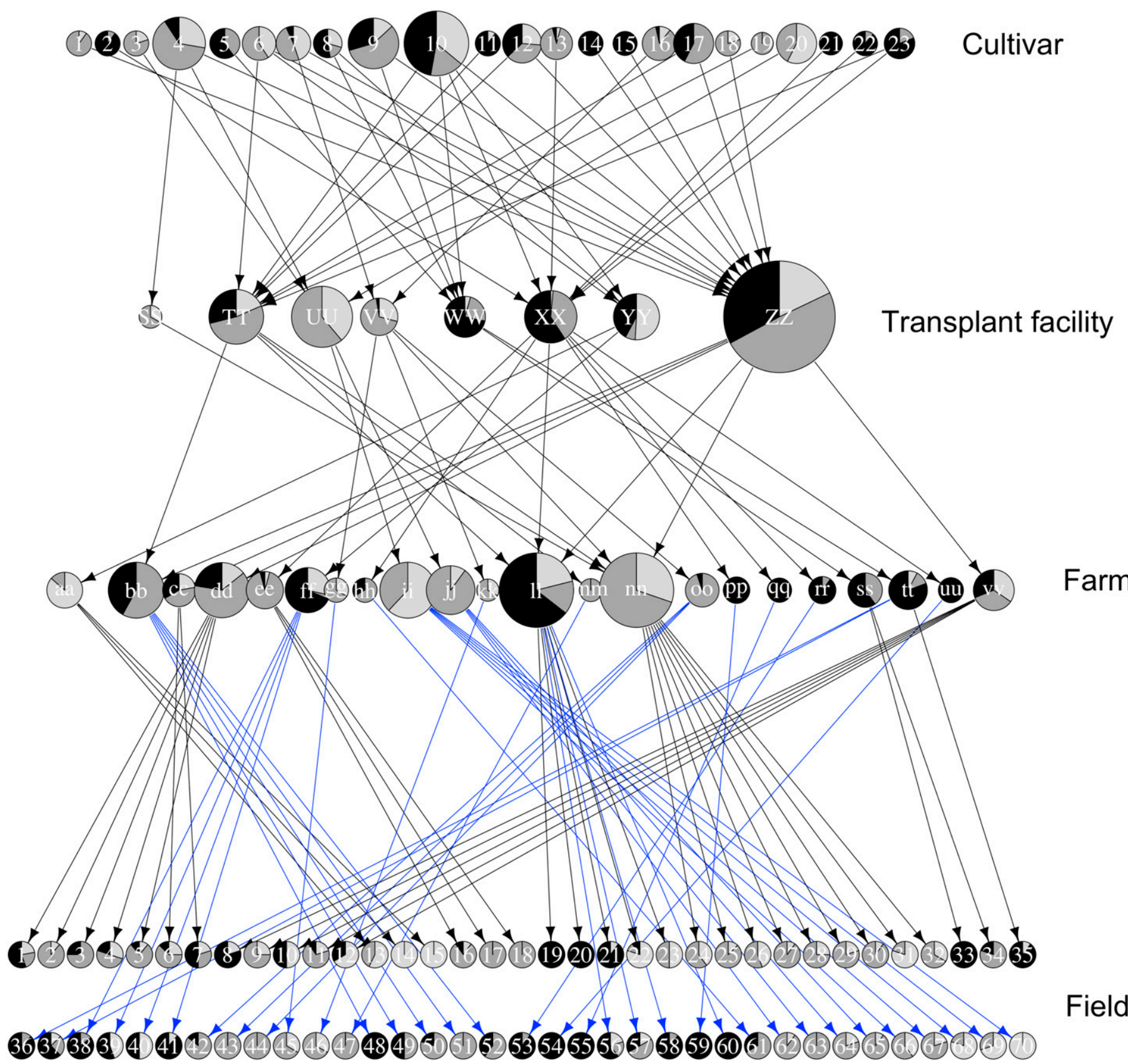

Fig. 3. Network showing sequence types across the tomato production system for the levels cultivar, transplant facility, farm, and field, with nodes (in rows) representing individuals in each level of the production system hierarchy and links indicating plant histories as they move through the system. All 585 strains from the collection are represented for each level of the production system. The size of each node corresponds to the number of strains evaluated for each individual (except for nodes representing fields, which are all shown in the same size for simplicity). The proportion of each sequence type within a category is depicted by the pie chart for each node. Black coloration represents sequence type 1 strains, medium gray represents sequence type 2 strains, and light gray represents sequence type 3 strains. Black and blue paths from farms to fields are to distinguish fields that are in the top and bottom row, respectively. 
the 12 farms and six of the seven transplant facilities shown in Figures 6 and 7, respectively, were associated with genetically and phenotypically diverse strains, represented by large ellipses on the corresponding plots (Figs. 6B and 7B and D). Several farms and transplant facilities appeared to be associated with certain strain types. Four farms and one transplant facility were associated with sequence types 2 and 3 and no sequence type 1 strains (Figs. 6C and 7C). Two farms were associated with sequence types 1 and 2 and no sequence type 3 strains (Fig. 6D). Two transplant facilities were associated mostly with sequence types 1 and 2, with a few sequence type 3 strains (Fig. 7D). In general, farms and transplant facilities that represented the largest number of strains and fields were the most diverse in NMDS plot analyses, reflecting at least in part the sampling effort. Supplementary Figures S4, S5, S6, S7, and S8 similarly show variables represented as ellipses with strain diversity associations for grower operation, county, region, cultivar, and seed producer, respectively.

TABLE 6. Presence of streptomycin resistance across tomato production system variables associated with sequence type 1 strains

\begin{tabular}{lccc}
\hline \multirow{2}{*}{$\begin{array}{l}\text { Tomato } \\
\text { production } \\
\text { variable }\end{array}$} & \multicolumn{3}{c}{ Number of categories (\% of total categories) ${ }^{\mathrm{a}}$} \\
\cline { 2 - 4 } & $\begin{array}{c}100 \% \text { of strains } \\
\text { were } \mathrm{Sm}^{\mathrm{r}}\end{array}$ & $\begin{array}{c}100 \% \text { of strains } \\
\text { were } \mathrm{Sm}^{\mathrm{s}}\end{array}$ & $\begin{array}{c}\text { Mixture of } \mathrm{Sm}^{\mathrm{r}} \text { and } \\
\mathrm{Sm}^{\mathrm{s}} \text { strains }\end{array}$ \\
\hline Field & $20(52.6)$ & $10(26.3)$ & $8(21.1)$ \\
Farm & $6(40.0)$ & $1(6.7)$ & $8(53.3)$ \\
$\begin{array}{l}\text { Transplant } \\
\text { facility }\end{array}$ & $1(16.7)$ & $1(16.7)$ & $4(66.7)$ \\
Cultivar & $10(58.9)$ & $2(11.8)$ & $5(29.4)$ \\
\hline
\end{tabular}

${ }^{\mathrm{a}} \mathrm{Sm}^{\mathrm{r}}=$ streptomycin resistant and $\mathrm{Sm}^{\mathrm{s}}=$ streptomycin sensitive.

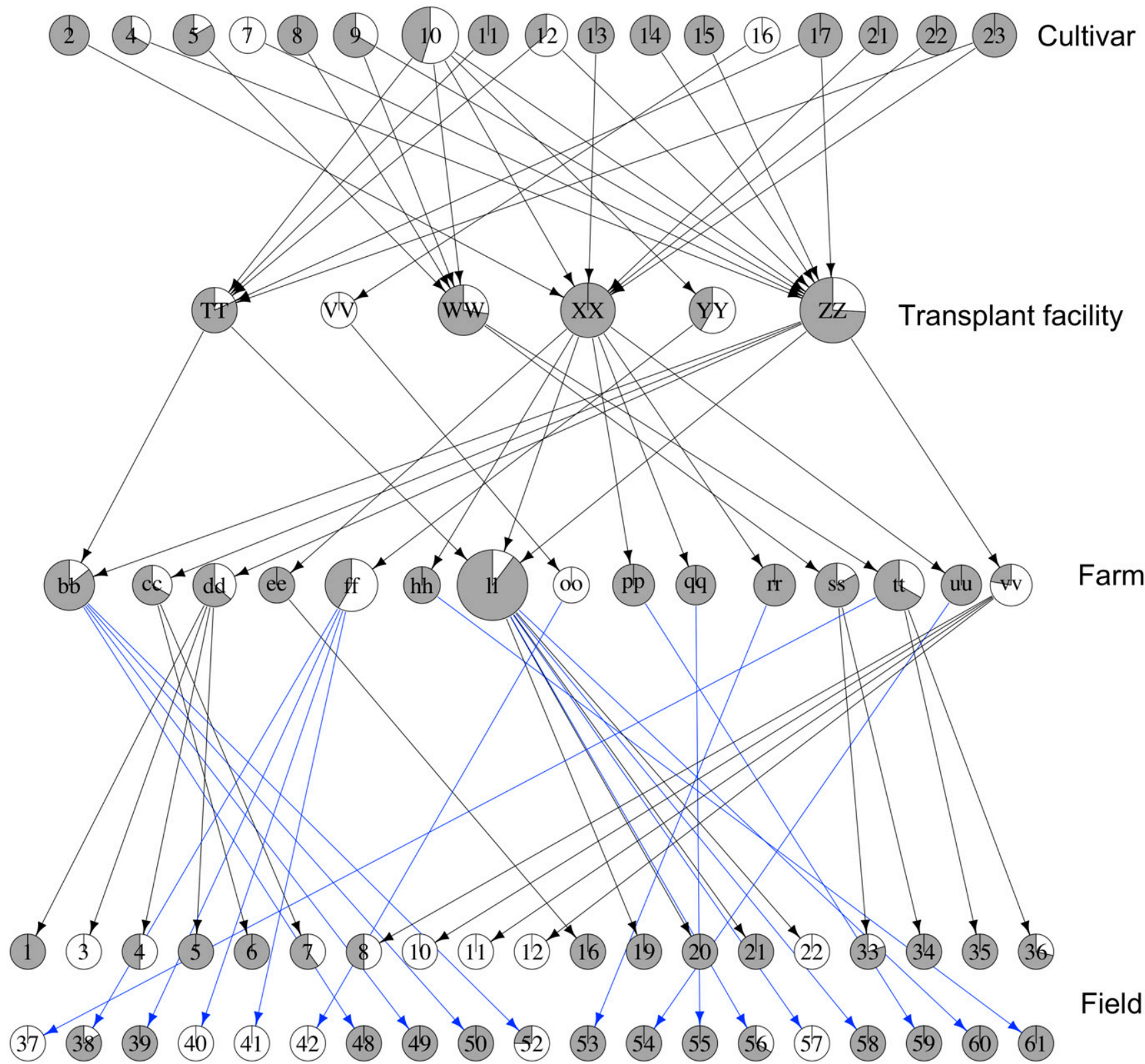

Fig. 4. Network showing streptomycin sensitivity in sequence type 1 strains, tested at $200 \mu \mathrm{g} / \mathrm{ml}$ of streptomycin sulfate, across the tomato production system for the levels cultivar, transplant facility, farm, and field. Nodes (in rows) represent individuals in each level of the production system hierarchy and links indicate plant histories as they move through the system. All sequence type 1 strains (188 strains) from the collection are represented for each level of the production system. The size of each node corresponds to the number of strains evaluated for each individual (except for nodes representing fields, which are all shown in the same size for simplicity). The proportion of streptomycin sensitivity within a category is depicted by the pie chart for each node. Gray coloration represents strains that are resistant to streptomycin and white represents strains that are sensitive to streptomycin. Black and blue paths from farms to fields are to distinguish fields that are in the top and bottom row, respectively. 


\section{DISCUSSION}

In this study, we characterized the BST population across 70 Florida tomato fields within one season, then combined characterization data with production system variables to identify potential associations. Our analyses indicated that there are differences in strain genotype and phenotype among tomato production system components, including differences among farms and transplant facilities, which suggests that these may be important points of pathogen entry and spread. We also identified novel effector profiles present at low frequencies in the population and observed that the Florida $X$. perforans population is continuing to shift in genotype and phenotype.

The frequency of streptomycin resistance in $X$. perforans field populations has continued to increase over time in Florida. X. perforans resistance to the bactericide was first identified in strains collected in 2006, when $5 \%$ of the Florida-wide collection was resistant to streptomycin, and prevalence increased to $14 \%$ of the strains collected from field samples in a 2011 to 2012 collection (Horvath et al. 2012; Vallad et al. 2013). Nearly one-quarter of strains in this 2017 collection were resistant to streptomycin. Streptomycin has not been labeled for field use on tomato in the United States since 1988 but is still permitted for transplant production. Interestingly, most of the sequence type 1 strains were streptomycin resistant, whereas only one sequence type 2 strain was streptomycin resistant. This finding calls into question whether the presence of streptomycin-resistant strains in a field is indicative of streptomycin applications during transplant production, since resistance may simply be attributable to the presence of sequence type 1 strains. Rare occurrence of streptomycin resistance in sequence type 2 , compared with the abundant resistance among sequence type 1 strains, suggests that there may be possible genetic differences in resistance mechanisms between sequence types, as well as potential differential effects of streptomycin resistance acquisition on fitness for each sequence type. Whole genome data and fitness studies are needed to confirm this hypothesis.

The frequency of copper tolerance has remained high in Florida strains of $X$. perforans, as found in previous statewide studies (Horvath et al. 2012; Vallad et al. 2013). Although growers have significantly reduced copper applications, its use is still common throughout Florida tomato production fields, as it is one of the few field treatments available against BST (Abrahamian et al. 2019a; StrayerScherer et al. 2018; Vallad et al. 2010, 2013). Unfortunately for growers, this continuous selection pressure appears to have maintained copper tolerance in the population. A reduction in copper treatment usage, as was done with streptomycin sulfate after resistance rapidly built up in the $X$. euvesicatoria population, could reduce selection pressure for the pathogen to maintain copper tolerance in the population, which may allow for effective usage of copper compounds in the future (Horvath et al. 2012; Thayer and Stall 1962).

Bacteriocin production is recognized as the main contributing factor for how $X$. perforans was able to replace $X$. euvesicatoria in the Florida population. Approximately half of the $X$. perforans strains in our collection produced bacteriocins against $X$. euvesicatoria. Despite the inability of nearly half of our strains to produce bacteriocins, we did not identify $X$. euvesicatoria in our collection. However, even with a limited number of samples per field, we were able to detect at least one bacteriocin producer in $88.6 \%$ of fields. Presence of some level of bacteriocin-producing strains in most fields, regardless of frequency, may be sufficient to prevent reintroduction of $X$. euvesicatoria into the Florida tomato production system. Adversely, the high proportion of strains that do not produce bacteriocins may also allow $X$. euvesicatoria to re-establish in the Florida tomato production system if $X$. euvesicatoria is present and spreads from upstream in the tomato production system. This is the first study to characterize $X$. perforans bacteriocin production for more than a handful of strains in Florida, so we are unable to compare the current bacteriocin production frequency with $X$. perforans populations in the early 1990s when X. euvesicatoria was still present on tomato in Florida. Sequence type 2 strains, which represented $45.7 \%$ of the total population, were determined to be bacteriocin negative when tested against $X$. euvesicatoria. A previous genomic study by Timilsina et al. (2019) established that sequence type 2 has been highly recombinant with $X$. euvesicatoria. We also discovered a range in bacteriocin inhibition zone sizes, as well as absence of bacteriocin production, for a small portion of sequence type 1 and 3 strains. The size range may be attributable to a difference in bacteriocin compounds produced, timing of production, reduction in amount of production, or other factors, but further study is needed to examine these hypotheses. The absence of bacteriocin production in these sequence types, or even a reduction, may allow for these strains to also coexist on tomato tissue with $X$. euvesicatoria and allow for recombination.

During initial isolation and identification of BST-causing Xanthomonas in our collection, we also discovered a small proportion (4.6\%) of strains that deviated from the typical $X$. perforans coloration identified in past studies. Different shades of yellow are common between various Xanthomonas species (Starr and Stephens 1964; Starr et al. 1977), although variation within $X$. perforans has not been noted in other reports or observed during the numerous worldwide strains our groups have collected and received. The diversity in color is noted to aid with future $X$. perforans diagnostics.

Previous studies have shown that the original $X$. perforans tomato race identified (T3) has been replaced by T4 despite the lack of any known cultivar selection (Horvath et al. 2012; Schwartz et al. 2015; Timilsina et al. 2016; Vallad et al. 2013). We discovered that a low frequency of T3 strains does still exist in the population and cannot be discounted in future tomato breeding efforts. We did not have access to a tomato line that could be used to reliably confirm T4 phenotype, so we were unable to confirm T4 status. Absence of xopJ4, which has been associated with T4 strain type (Astua-Monge et al. 2000b; Schwartz et al. 2015), in some of our strains suggests that this collection may contain strains from a new $X$. perforans tomato race, but this needs to be phenotypically confirmed. Further study is also needed to understand the molecular mechanisms of pathogen-host interactions between $X$. perforans sequence types and pepper. Previous $X$. perforans isolated from tomato had not

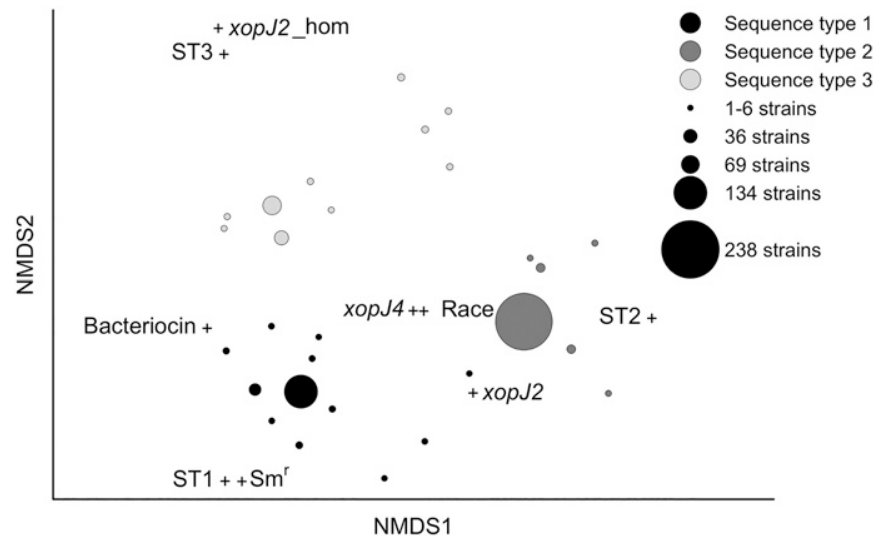

Fig. 5. Nonmetric multidimensional scaling (NMDS) plot depicting characterization data for all 585 Xanthomonas perforans strains by nine binary categorical variables (xорJ2, xорJ2 homolog, xорJ4, sequence type 1, sequence type 2 , sequence type 3 , tomato race, bacteriocin production, and streptomycin sulfate resistance). Each point represents one or more strains and the distance between two points is generally inversely proportional to the similarity between the two types of strains represented by the two points. The size of the point is proportional to the number of strains that are the same based on the nine categorical variables described above, using a logarithmic scale. Point color depicts the sequence type (ST) that strains belong to, and strains of different STs are generally separated in the plot because ST is included in the set of categorical variables. The data for effectors xopJ2, хорJ2 homolog (xорJ2_hom), and xopJ4, as well as the ability to produce bacteriocins (Bacteriocin) and grow on nutrient agar amended with $200 \mu \mathrm{g} / \mathrm{ml}$ of streptomycin sulfate $\left(\mathrm{Sm}^{\mathrm{r}}\right.$ = streptomycin resistant), were analyzed in binary form (presence or absence). All strains were identified as either tomato race T3 or T4 (Race) by differential plant inoculations. 
been identified as pepper pathogenic, although one strain, Xp2010, has been isolated from pepper and confirmed as a pepper pathogen (Schwartz et al. 2015; Timilsina et al. 2016, 2019). Inability of $X$. perforans to expand to pepper was thought to be attributable, at least in part, to the presence of XopJ2 and XopAF (Schwartz et al. 2015). Schwartz et al. (2015) proposed that restriction of host expansion was also attributable to additional factors, but these have not been identified yet. Most of our strains elicited an atypical HR on pepper plants, which appears to be a weaker form of HR, and some did not elicit any HR. Only a small proportion of our strains displayed the characteristic HR that was described as associated with $X$. perforans. The only strict associations we could identify with pepper phenotype and strain genotype were that all of the strains that elicited a typical HR were sequence type 1, the same sequence type as the strains that were used to establish the association of $X$. perforans to pepper HR (Schwartz et al. 2015), and that all strains that contained xорJ2 or хорAF elicited some degree of an HR. The mechanisms of $X$. perforans pepper pathogenicity are not known, so we were unable confirm whether the weak HR observed was attributable to a resistant plant response.

Identification of the simple presence and absence of genes for four effectors revealed a large repertoire of $X$. perforans effector genetic diversity. We identified 13 unique combinations of the four effectors, some of which have not been previously reported. We discovered two novel strains that appear to lack all four effector genes and belong to sequence type 3. Results from this study put into question the established associations between effector presence or absence (for xopAF, xopJ4, and xopJ2) and tomato race and pepper pathogenicity (AstuaMonge et al. 2000a, b; Horvath et al. 2012; Minsavage et al. 1990; Schwartz et al. 2015), as distinct effector profiles did not strictly align with particular plant phenotypes. Other factors are likely involved, as proposed by Schwartz et al. (2015). For example, presence of xopAF has been associated with T3 strains (Astua-Monge et al. 2000a); however, we identified strains that either did not appear to contain $x o p A F$, contained a large insertion sequence in $x o p A F$, or contained mutations in the gene sequence, which each tested as T3 phenotypically.
Sequencing of the strains from this collection, especially those with atypical genotype-phenotype associations, is needed to confirm presence and sequence identity with effectors that appeared as present via PCR amplification of parts of the genes.

We used NMDS and network analysis to look for associations between our plant history metadata and strain characterization data to identify potential pathogen entry points into the Florida tomato production system. Although we collected a large amount of production system metadata, there are additional factors that are likely also important. We do not have data regarding which particular greenhouse within a transplant facility these plants were grown in and at what time, where they could have been exposed to different pathogen strains from within the greenhouse, workers, or equipment moving between greenhouses, or nearby plants from other seed lots. Also, we do not have data regarding which country, or region within a country, each field's seed lot was produced from, so we do not know whether plants from two different fields that were the same cultivar were actually produced in a nearby place at the same time. We do not account for the timing of sampling, both at the calendar level and the stage of production the field was in. Although tomatoes are produced year-round in Florida, each region has distinct production window(s) throughout the year owing to different seasonal weather patterns. Cultivars, or plant genotypes, grown also tend to differ between northern Florida and other parts of Florida. For simplicity, we group plants as coming from the same category within a tomato production variable, such as a particular transplant facility, but there can be a lot of variation within each category. As more information about the structure of seed and transplant production networks is available for pathosystems such as BST, it will be useful for understanding not only the movement of pathogen species through the networks but also the flow of key genotypes (Garrett et al. 2018; Shaw and Pautasso 2014). Understanding the structures of the networks will support sampling and mitigation strategies to detect important new genotypes before they have spread widely and become established in fields (Andersen et al. 2019; Buddenhagen et al. 2017; Nelson and Bone 2015).
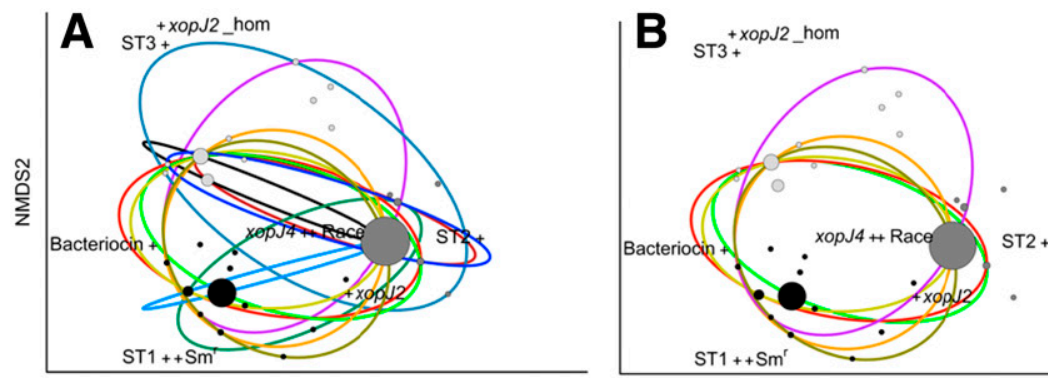

\begin{tabular}{|c|c|c|c|c|c|}
\hline Farm & ID & $\begin{array}{c}\# \\
\text { Strains }\end{array}$ & $\begin{array}{c}\# \\
\text { Fields }\end{array}$ & $\begin{array}{c}\# \\
\text { Cultivars }\end{array}$ & $\begin{array}{c}\# \\
\text { Transplant } \\
\text { facilities }\end{array}$ \\
\hline & aa & 22 & 3 & 3 & 1 \\
\hline & $b b$ & 50 & 5 & 2 & 2 \\
\hline & $\mathrm{dd}$ & 49 & 5 & 1 & 1 \\
\hline & ee & 24 & 3 & 1 & 1 \\
\hline & $\mathrm{ff}$ & 35 & 4 & 1 & 1 \\
\hline & ii & 50 & 5 & 2 & 1 \\
\hline & jj & 40 & 4 & 2 & 1 \\
\hline & II & 76 & 9 & 8 & 3 \\
\hline & $\mathrm{nn}$ & 76 & 9 & 5 & 4 \\
\hline & SS & 20 & 2 & 1 & 1 \\
\hline & $\mathrm{tt}$ & 26 & 3 & 3 & 1 \\
\hline & vv & 29 & 5 & 3 & 1 \\
\hline
\end{tabular}
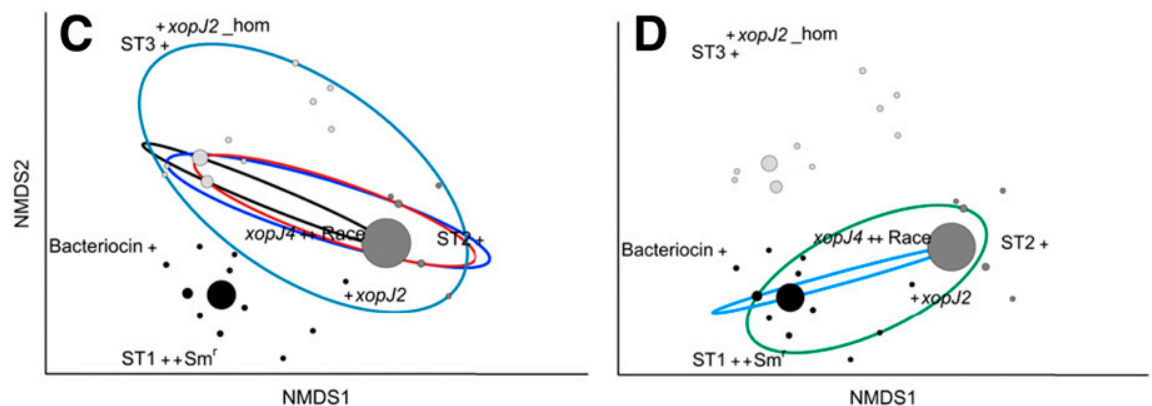

Fig. 6. Nonmetric multidimensional scaling (NMDS) plots depicting ordination of all 585 Xanthomonas perforans strains with ellipses drawn indicating individual farms. Figure 5 contains detailed information regarding the base NMDS plot used. The 585 strains were collected from a total of 22 farms, but only the 12 farms that had $\geq 20$ representative strains in the collection are shown. Each ellipse encloses the points representing strains from one farm. The right-hand table provides information regarding how many categories of other variables are represented for each farm to visualize how diverse plant history is for each farm's collective plant samples. A, Depicts ellipses from all 12 farms. To visualize ellipses and patterns more easily, ellipses from A were separated into B to D by farms with similar strain patterns. B, Highlights farms that contain strains with a diversity of phenotypes and genotypes. C, Highlights farms that contain sequence type 2 and 3 strains but do not contain sequence type 1 strains. D, Highlights farms that contain a high proportion of sequence type 2 strains but do not contain sequence type 3 strains. $\mathrm{ST}=$ sequence type, hom $=$ homolog, $\mathrm{Sm}^{\mathrm{r}}=$ streptomycin resistant, and $\mathrm{ID}=$ identifier . 
Hurricane Irma moved through Florida (moving from South to North Florida) in early September during the year of this collection (2017), causing varying levels of disruption to tomato fields and transplant production facilities throughout the state. Growers in southeast Florida had not planted and were minimally impacted. Growers in southwest Florida were just beginning to plant fields and some moved their transplants out of the state until the storm passed. Most tomato fields in northwest and central-west Florida were planted prior to Hurricane Irma, but only sustained minor damage. Several transplant facilities in southern Florida were severely damaged. Xanthomonas species that cause BST are known to disperse via wind and rain (Bernal and Berger 1996; McInnes et al. 1988), and other studies with citrus canker-causing $X$. citri have shown even more dramatic dispersion of wind-driven rain, such as events caused by a hurricane (Bock et al. 2005, 2010; Gottwald and Irey 2007; Graham et al. 2004). Dispersal of $X$. perforans strains via Hurricane Irma may account for the large diversity of strains we observed across Florida tomato production fields.

We did not expect to identify as many as three sequence types within a single production field, especially with a limited sample size of approximately $\leq 10$ strains per field. Although we had extensive metadata for each isolated strain, it proved difficult to identify associations between strain characteristics and plant history given the high level of population diversity. However, some farms and transplant facilities tended to be associated with certain sequence types and therefore certain strain characteristics. Overall, we tended to observe the lowest amount of pathogen diversity with fields, farms, and transplant facilities that were associated with lower numbers of categories from other tomato production system variables. This information would suggest that strains may be spreading within farms and transplant facilities, which could be attributable to local sources of $X$. perforans on weeds, volunteer tomato plants, plant debris, and on equipment. Further spread could be easily facilitated by the movement of contaminated plants, people, equipment, and weather events, which may explain the diverse populations observed at other farms and transplant facilities. Abrahamian et al. (2021) demonstrated the role of aerosols in the rapid movement of $X$. perforans with the use of overhead irrigation during transplant production.

Our approach of sampling a smaller number of plants from across a large number of fields, and characterizing all strains, achieved our goals of determining the overall diversity across Florida tomato production and identifying phenotypes and genotypes present at low frequency in the population. Most Florida growers outsource their transplant production to companies that grow transplants for multiple growers. Therefore, we decided on our current collection strategy to capture associations across a wide range of growers and other production system categories in Florida and focused our effort on collecting samples from a large number of fields. Additional studies could potentially further resolve strain relationships by directly sampling other production system variables.

We conclude that the Xanthomonas pathogen population is very diverse at the field level, which may reflect the complexity of the Florida tomato production system. By characterizing all strains within our large collection for all phenotypes and genotypes tested, we identified novel and diverse strain types occurring at lower frequencies that may not have been identified otherwise. The population structure is also complex, although we did identify some trends associated with particular production system variables. We were unable to more closely associate tomato production system categories with particular strain genotypes. Higher-resolution data for each strain, such as from whole genome sequencing, may allow us to distinguish between strains that appear to be identical based on our current characterization data. Knowledge of pathogen diversity and population shifts can lead to improved management strategies via the development and deployment of plant resistance and other prophylactic measures. Insights gained and lessons learned regarding sampling and characterization approaches taken in this study can
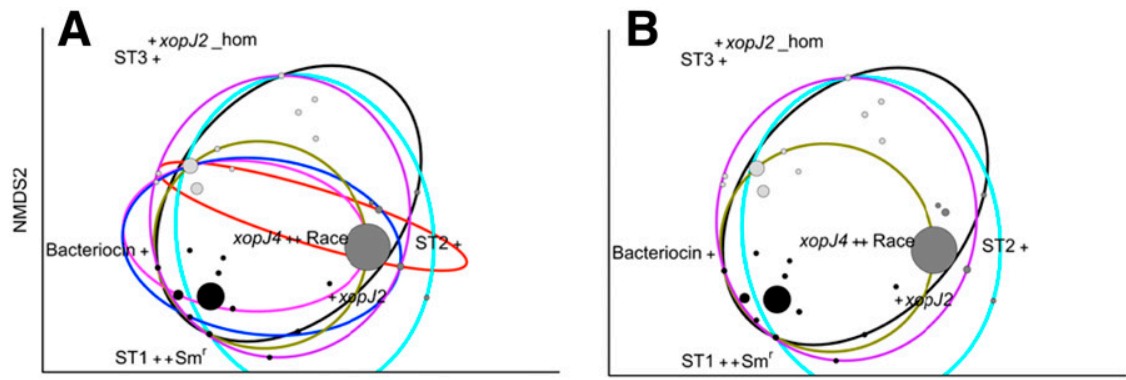

\begin{tabular}{cccccc}
$\begin{array}{c}\text { Transplant } \\
\text { facility }\end{array}$ & ID & $\begin{array}{c}\# \\
\text { Strains }\end{array}$ & $\begin{array}{c}\# \\
\text { Fields }\end{array}$ & $\begin{array}{c}\# \\
\text { Farms }\end{array}$ & $\begin{array}{c}\# \\
\text { Cultivars }\end{array}$ \\
\hline TI & 76 & 9 & 4 & 7 \\
& UU & 90 & 9 & 2 & 3 \\
VV & 38 & 6 & 4 & 2 \\
& WW & 46 & 5 & 2 & 4 \\
& XX & 71 & 9 & 7 & 6 \\
YY & 57 & 7 & 2 & 3 \\
ZZ & 201 & 24 & 6 & 11
\end{tabular}
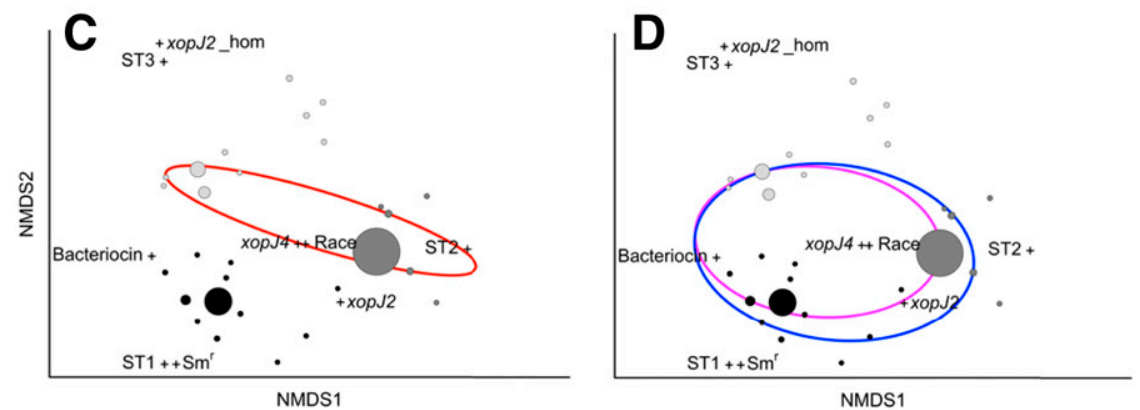

Fig. 7. Nonmetric multidimensional scaling (NMDS) plots depicting ordination of all 585 Xanthomonas perforans strains with ellipses drawn indicating individual transplant facilities. Figure 5 contains detailed information regarding the base NMDS plot used. The 585 strains were collected from plants that originated from a total of eight transplant facilities, but only the seven transplant facilities that had $\geq 20$ representative strains in the collection are shown. Each ellipse encloses the points representing strains from plants originating at one transplant facility. The right-hand table provides information regarding how many categories of other variables are represented for each transplant facility to visualize how diverse plant history is for each facility's collective plant samples. A, Depicts ellipses from all seven transplant facilities. To visualize ellipses and patterns more easily, ellipses from A were separated as B to D by transplant facilities with more similar strain patterns. B, Highlights transplant facilities that are associated with strains with a diversity of phenotypes and genotypes. C, Highlights a facility that is associated with sequence type 2 and 3 strains but not sequence type 1 strains. D, Highlights facilities that are associated with little to no sequence type 3 strains and a high proportion of sequence type 1 strains. $\mathrm{ST}=$ sequence type, hom $=$ homolog, $\mathrm{Sm}^{\mathrm{r}}=$ streptomycin resistant, and ID = identifier. 
aid in similar efforts for other pathogens and agricultural production systems.

\section{ACKNOWLEDGMENTS}

We thank Qiurong Fan and Fanny B. Iriarte for help with initial strain isolations from northern Florida, and Pamela Roberts for sampling efforts in southwestern Florida.

\section{LITERATURE CITED}

Abrahamian, P. 2017. Fitness, molecular characterization and management of bacterial leaf spot in tomatoes. Ph.D. thesis, University of Florida, Gainesville, FL.

Abrahamian, P., Jones, J. B., and Vallad, G. E. 2019a. Efficacy of copper and copper alternatives for management of bacterial spot on tomato under transplant and field production. Crop Prot. 126:104919.

Abrahamian, P., Sharma, A., Jones, J., and Vallad, G. E. 2021. Dynamics and spread of bacterial spot epidemics in tomato transplants grown for field production. Plant Dis. 105:566-575.

Abrahamian, P., Timilsina, S., Minsavage, G. V., Potnis, N., Jones, J. B., Goss, E. M., and Vallad, G. E. 2019b. Molecular epidemiology of Xanthomonas perforans outbreaks in tomato plants from transplant to field as determined by single-nucleotide polymorphism analysis. Appl. Environ. Microbiol. 85: e01220-19.

Altschul, S. F., Gish, W., Miller, W., Myers, E. W., and Lipman, D. J. 1990. Basic local alignment search tool. J. Mol. Biol. 215:403-410.

Andersen, K. F., Buddenhagen, C. E., Rachkara, P., Gibson, R., Kalule, S., Phillips, D., and Garrett, K. A. 2019. Modeling epidemics in seed systems and landscapes to guide management strategies: The case of sweet potato in northern Uganda. Phytopathology 109:1519-1532.

Astua-Monge, G., Minsavage, G. V., Stall, R. E., Davis, M. J., Bonas, U., and Jones, J. B. 2000a. Resistance of tomato and pepper to T3 strains of Xanthomonas campestris pv. vesicatoria is specified by a plant-inducible avirulence gene. Mol. Plant-Microbe Interact. 13:911-921.

Astua-Monge, G., Minsavage, G. V., Stall, R. E., Vallejos, C. E., Davis, M. J., and Jones, J. B. 2000b. Xv4-vrxv4: A new gene-for-gene interaction identified between Xanthomonas campestris pv. vesicatoria race T3 and wild tomato relative Lycopersicon pennellii. Mol. Plant-Microbe Interact. 13: 1346-1355.

Barak, J. D., Vancheva, T., Lefeuvre, P., Jones, J. B., Timilsina, S., Minsavage, G. V., Vallad, G. E., and Koebnik, R. 2016. Whole-genome sequences of Xanthomonas euvesicatoria strains clarify taxonomy and reveal a stepwise erosion of type 3 effectors. Front. Plant Sci. 7:1805.

Bernal, R. F., and Berger, R. D. 1996. The spread of epiphytic populations of Xanthomonas campestris pv. vesicatoria on pepper in the field. J. Phytopathol. 144:479-484.

Bock, C. H., Graham, J. H., Gottwald, T. R., Cook, A. Z., and Parker, P. E. 2010. Wind speed effects on the quantity of Xanthomonas citri subsp. citri dispersed downwind from canopies of grapefruit trees infected with citrus canker. Plant Dis. 94:725-736.

Bock, C. H., Parker, P. E., and Gottwald, T. R. 2005. Effect of simulated winddriven rain on duration and distance of dispersal of Xanthomonas axonopodis pv. citri from canker-infected citrus trees. Plant Dis. 89:71-80.

Buddenhagen, C. E., Hernandez Nopsa, J. F., Andersen, K. F., Andrade-Piedra, J., Forbes, G. A., Kromann, P., Thomas-Sharma, S., Useche, P., and Garrett, K. A. 2017. Epidemic network analysis for mitigation of invasive pathogens in seed systems: Potato in Ecuador. Phytopathology 107:1209-1218.

Constantin, E. C., Cleenwerck, I., Maes, M., Baeyen, S., Van Malderghem, C., De Vos, P., and Cottyn, B. 2016. Genetic characterization of strains named as Xanthomonas axonopodis pv. dieffenbachiae leads to a taxonomic revision of the $X$. axonopodis species complex. Plant Pathol. 65:792-806.

Csardi, G., and Nepusz, T. 2006. The igraph software package for complex network research. InterJ Complex Syst. 1695:1-9.

Edgar, R. C. 2004. MUSCLE: Multiple sequence alignment with high accuracy and high throughput. Nucleic Acids Res. 32:1792-1797.

Garrett, K. A., Alcalá-Briseño, R. I., Andersen, K. F., Buddenhagen, C. E., Choudhury, R. A., Fulton, J. C., Hernandez Nopsa, J. F., Poudel, R., and Xing, Y. 2018. Network analysis: A systems framework to address grand challenges in plant pathology. Annu. Rev. Phytopathol. 56:559-580.

Gottwald, T. R., and Irey, M. 2007. Post-hurricane analysis of citrus canker II: Predictive model estimation of disease spread and area potentially impacted by various eradication protocols following catastrophic weather events. Plant Health Prog. 8:22.

Graham, J. H., Gottwald, T. R., Cubero, J., and Achor, D. S. 2004. Xanthomonas axonopodis pv. citri: Factors affecting successful eradication of citrus canker. Mol. Plant Pathol. 5:1-15.
Hert, A. P., Marutani, M., Momol, M. T., Roberts, P. D., Olson, S. M., and Jones, J. B. 2009. Suppression of the bacterial spot pathogen Xanthomonas euvesicatoria on tomato leaves by an attenuated mutant of Xanthomonas perforans. Appl. Environ. Microbiol. 75:3323-3330.

Hert, A. P., Roberts, P. D., Momol, M. T., Minsavage, G. V., Tudor-Nelson, S. M., and Jones, J. B. 2005. Relative importance of bacteriocin-like genes in antagonism of Xanthomonas perforans tomato race 3 to Xanthomonas euvesicatoria tomato race 1 strains. Appl. Environ. Microbiol. 71:35813588.

Horvath, D. M., Stall, R. E., Jones, J. B., Pauly, M. H., Vallad, G. E., Dahlbeck, D., Staskawicz, B. J., and Scott, J. W. 2012. Transgenic resistance confers effective field level control of bacterial spot disease in tomato. PLoS One 7:e42036

Iruegas-Bocardo, F., Abrahamian, P., Minsavage, G. V., Potnis, N., Vallad, G. E., Jones, J. B., and Goss, E. M. 2018. XopJ6, a new member of the XopJ family of type III effectors, in Xanthomonas perforans. Phytopathology 108:37.

Jones, J. B., Bouzar, H., Somodi, G. C., Stall, R. E., Pernezny, K., El-Morsy, G., and Scott, J. W. 1998. Evidence for the preemptive nature of tomato race 3 of Xanthomonas campestris pv. vesicatoria in Florida. Phytopathology 88:33-38.

Jones, J. B., Lacy, G. H., Bouzar, H., Minsavage, G. V., Stall, R. E., and Schaad, N. W. 2005. Bacterial spot- worldwide distribution, importance, and review. Acta Hortic. 695:27-34.

Jones, J. B., Lacy, G. H., Bouzar, H., Stall, R. E., and Schaad, N. W. 2004. Reclassification of the xanthomonads associated with bacterial spot disease of tomato and pepper. Syst. Appl. Microbiol. 27:755-762.

Jones, J. B., Pohronezny, K. L., Stall, R. E., and Jones, J. P. 1986. Survival of Xanthomonas campestris pv. vesicatoria in Florida on tomato crop residue, weeds, seeds, and volunteer tomato plants. Phytopathology 76:430-434.

Kebede, M., Timilsina, S., Ayalew, A., Admassu, B., Potnis, N., Minsavage, G. V., Goss, E. M., Hong, J. C., Strayer, A., Paret, M., Jones, J. B., and Vallad, G. E. 2014. Molecular characterization of Xanthomonas strains responsible for bacterial spot of tomato in Ethiopia. Eur. J. Plant Pathol. 140:677-688.

Klein, J. M., Stockwell, V. O., Minsavage, G. V., Vallad, G. E., Goss, E. M., and Jones, J. B. 2020. Improved deferred antagonism technique for detecting antibiosis. Lett. Appl. Microbiol. 71:330-336.

Kunwar, S., Iriarte, F., Fan, Q., Evaristo da Silva, E., Ritchie, L., Nguyen, N. S., Freeman, J. H., Stall, R. E., Jones, J. B., Minsavage, G. V., Colee, J., Scott, J. W., Vallad, G. E., Zipfel, C., Horvath, D., Westwood, J., Hutton, S. F., and Paret, M. L. 2018. Transgenic expression of EFR and $B s 2$ genes for field management of bacterial wilt and bacterial spot of tomato. Phytopathology 108:1402-1411.

McInnes, T. B., Gitaitis, R. D., McCarter, S. M., Jaworski, C. A., and Phatak, S. C. 1988. Airborne dispersal of bacteria in tomato and pepper transplant fields. Plant Dis. 72:575-579.

Micallef, L., and Rodgers, P. 2014. eulerAPE: Drawing area-proportional 3-Venn diagrams using ellipses. PLoS One 9:e101717.

Minsavage, G. V., Dahlbeck, D., Whalen, M. C., Kearney, B., Bonas, U., Staskawicz, B. J., and Stall, R. E. 1990. Gene-for-gene relationships specifying disease resistance in Xanthomonas campestris pv. vesicatoria-pepper interactions. Mol. Plant-Microbe Interact. 3:41-47.

Nelson, M. F., and Bone, C. E. 2015. Effectiveness of dynamic quarantines against pathogen spread in models of the horticultural trade network. Ecol. Complex. 24:14-28.

Notredame, C., Higgins, D. G., and Heringa, J. 2000. T-Coffee: A novel method for fast and accurate multiple sequence alignment. J. Mol. Biol. 302:205-217.

Oksanen, J., Blanchet, F. G., Friendly, M., Kindt, R., Legendre, P., McGlinn, D., Minchin, P. R., O'Hara, R. B., Simpson, G. L., Solymos, P., Stevens, M. H. H., Szoecs, E., and Wagner, H. 2019. Vegan: Community ecology package.

Pohronezny, K., and Volin, R. B. 1983. The effect of bacterial spot on yield and quality of fresh market tomatoes. HortScience 18:69-70.

Potnis, N., Krasileva, K., Chow, V., Almeida, N. F., Patil, P. B., Ryan, R. P., Sharlach, M., Behlau, F., Dow, J. M., Momol, M. T., White, F. F., Preston, J. F., Vinatzer, B. A., Koebnik, R., Setubal, J. C., Norman, D. J., Staskawicz, B. J., and Jones, J. B. 2011. Comparative genomics reveals diversity among xanthomonads infecting tomato and pepper. BMC Genomics 12:146.

Potnis, N., Timilsina, S., Strayer, A., Shantharaj, D., Barak, J. D., Paret, M. L., Vallad, G. E., and Jones, J. B. 2015. Bacterial spot of tomato and pepper: Diverse Xanthomonas species with a wide variety of virulence factors posing a worldwide challenge. Mol. Plant Pathol. 16:907-920.

R Core Team. 2020. R: A language and environment for statistical computing. R Foundation for Statistical Computing, Vienna, Austria.

Schwartz, A. R., Potnis, N., Timilsina, S., Wilson, M., Patané, J., Martins, J., Jr., Minsavage, G. V., Dahlbeck, D., Akhunova, A., Almeida, N., Vallad, G. E., Barak, J. D., White, F. F., Miller, S. A., Ritchie, D., Goss, E., Bart, 
R. S., Setubal, J. C., Jones, J. B., and Staskawicz, B. 2015. Phylogenomics of Xanthomonas field strains infecting pepper and tomato reveals diversity in effector repertoires and identifies determinants of host specificity. Front. Microbiol. 6:535.

Shaw, M. W., and Pautasso, M. 2014. Networks and plant disease management: Concepts and applications. Annu. Rev. Phytopathol. 52:477-493.

Sijam, K., Chang, C. J., and Gitaitis, R. D. 1991. An agar medium for the isolation and identification of Xanthomonas campestris pv. vesicatoria from seed. Phytopathology 81:831-834.

Stall, R. E., Jones, J. B., and Minsavage, G. V. 2009. Durability of resistance in tomato and pepper to xanthomonads causing bacterial spot. Annu. Rev. Phytopathol. 47:265-284.

Starr, M. P., Jenkins, C. L., Bussey, L. B., and Andrewes, A. G. 1977. Chemotaxonomic significance of the xanthomonadins, novel brominated arylpolyene pigments produced by bacteria of the genus Xanthomonas. Arch. Microbiol. 113:1-9.

Starr, M. P., and Stephens, W. L. 1964. Pigmentation and taxonomy of the genus Xanthomonas. J. Bacteriol. 87:293-302.

Strayer, A. L., Jeyaprakash, A., Minsavage, G. V., Timilsina, S., Vallad, G. E., Jones, J. B., and Paret, M. L. 2016. A multiplex real-time PCR assay differentiates four Xanthomonas species associated with bacterial spot of tomato. Plant Dis. 100:1660-1668.

Strayer-Scherer, A., Liao, Y. Y., Young, M., Ritchie, L., Vallad, G. E., Santra, S., Freeman, J. H., Clark, D., Jones, J. B., and Paret, M. L. 2018. Advanced copper composites against copper-tolerant Xanthomonas perforans and tomato bacterial spot. Phytopathology 108:196-205.

Thayer, P., and Stall, R. E. 1962. A survey of Xanthomonas vesicatoria resistance to streptomycin. FL Ag Exp Stations J 1523:163-165.

Timilsina, S., Abrahamian, P., Potnis, N., Minsavage, G. V., White, F. F., Staskawicz, B. J., Jones, J. B., Vallad, G. E., and Goss, E. M. 2016. Analysis of sequenced genomes of Xanthomonas perforans identifies candidate targets for resistance breeding in tomato. Phytopathology 106:1097-1104.
Timilsina, S., Jibrin, M. O., Potnis, N., Minsavage, G. V., Kebede, M., Schwartz, A., Bart, R., Staskawicz, B., Boyer, C., Vallad, G. E., Pruvost, O., Jones, J. B., and Goss, E. M. 2015. Multilocus sequence analysis of xanthomonads causing bacterial spot of tomato and pepper plants reveals strains generated by recombination among species and recent global spread of Xanthomonas gardneri. Appl. Environ. Microbiol. 81:1520-1529.

Timilsina, S., Pereira-Martin, J. A., Minsavage, G. V., Iruegas-Bocardo, F., Abrahamian, P., Potnis, N., Kolaczkowski, B., Vallad, G. E., Goss, E. M., and Jones, J. B. 2019. Multiple recombination events drive the current genetic structure of Xanthomonas perforans in Florida. Front. Microbiol. 10:448.

Tudor-Nelson, S. M., Minsavage, G. V., Stall, R. E., and Jones, J. B. 2003. Bacteriocin-like substances from tomato race 3 strains of Xanthomonas campestris pv. vesicatoria. Bacteriology 93:1415-1421.

U.S. Department of Agriculture. 2019. USDA vegetables 2018 summary. U.S. Department of Agriculture National Agricultural Statistics Service, Washington, DC.

Vallad, G. E., Pernezny, K. L., Balogh, B., Wen, A., Figueiredo, J. F. L., Jones, J. B., Momol, T., Muchovej, R. M., Havranek, N., Abdallah, N., Olson, S., and Roberts, P. D. 2010. Comparison of kasugamycin to traditional bactericides for the management of bacterial spot on tomato. HortScience 45:18341840.

Vallad, G. E., Timilsina, S., Adkison, H., Potnis, N., Minsavage, G., Jones, J., and Goss, E. 2013. A recent survey of xanthomonads causing bacterial spot of tomato in Florida provides insights into management strategies. Tomato Inst. Proc. 2013:25-27.

VanSickle, J., and Weldon, R. 2009. The economic impact of bacterial leaf spot on the tomato industry. Tomato Inst. Proc. 2009:30-31.

Wickham, H., Averick, M., Bryan, J., Chang, W., McGowan, L. D., François, R., Grolemund, G., Hayes, A., Henry, L., Hester, J., Kuhn, M., Pedersen, T. L., Miller, E., Bache, S. M., Müller, K., Ooms, J., Robinson, D., Seidel, D. P., Spinu, V., Takahashi, K., Vaughan, D., Wilke, C., Woo, K., and Yutani, H. 2019. Welcome to the tidyverse. J. Open Source Softw. 4:1686. 